\title{
ENTREVISTA COM MARCO ANTONIO DA SILVA MELLO
}

\author{
Felipe Berocan Veiga ${ }^{1}$ \\ Hélio R. S. Silva ${ }^{2}$
}

Hélio Silva - Uma pergunta bem ampla, para começar. Usarei a expressão de Malinowski: qual o alcance e quais os limites ou limitações dos métodos etnográficos?

Marco Antonio - Essa questão suscita muita coisa. Sobretudo, referente ao próprio Malinowski. Malinowski era um homem muito sofisticado, um homem que falava seis línguas vivas - acho que no mínimo -, além de conhecer profundamente... tanto que usa, em seu caderno de campo, grego, latim, enfim, um homem sofisticado. Um homem formado na Cracóvia (com uma formação clássica) e que, ao escolher o próprio título do seu livro, Os Argonautas do Pacífico Ocidental, não precisava explicar para nenhum leitor em 1922, tanto na Inglaterra, quanto na Polônia neste momento as implicações deste título, evocação de um episódio fundamental na literatura. Já no título introduz uma questão que vai atravessar todo livro. Além disso, a referência a Frazer. Não se trata apenas de se legitimar. A presença de Frazer lembra as relações entre o tema do Malinowski e a grande inquietação de Frazer. Basta ver o final do O Ramo de Ouro quando ele diz que "nossa viagem chegou ao fim. Nossa embarcação está com as velas drapejando, cansadas, rasgadas" Enfim, a ideia de uma viagem, de um deslocamento físico. Não é uma viagem intelectual só. É uma viagem que implica um deslocamento físico e isto está inserido no próprio termo, nos próprios radicais gregos que estão nos Argonautas, a palavra argos. Então, essa busca que está no centro de qualquer investigação científica, e não só científica, mas em qualquer inquietação, mesmo de apreensão estética do mundo. Essa possibilidade de apreender o mundo reflexivamente. Aristóteles falava desse espanto, dessa súbita reflexividade, que surge às vezes em momentos de crise, significando essa súbita reflexividade, aguda reflexividade. A inquietação de Malinowski. Não se pode esquecer que ele era um físico formado, tinha feito como muitos outros de sua geração, que vinham também das ciências naturais. Química, como era o caso de Florian Znaniecki, contemporâneo de Malinowski, e

\footnotetext{
${ }^{1}$ Universidade Federal Fluminense, Brasil.

${ }^{2}$ Faculdade de Educação da Baixada Fluminense/Universidade do Estado do Rio de Janeiro, Brasil.
} 
muitos outros. A ideia de observação, a ideia de intervenção nos fenômenos, mas de qualquer maneira uma tradição intelectual que não descuidava da descrição desses fenômenos, tanto no campo das ciências naturais como ele vai fazer, retomando uma tradição, não necessariamente das ciências naturais, a observação do mundo social. E exercita isso de maneira muito, muito, sofisticada. Há nos Argonautas uma reflexão sobre a própria sociedade do observador, sobre a ideia de valor, sobre a ideia de entesouramento, sobre a ideia de cerimônia e sobre como os objetos vêm envolvidos, encapsulados, entretecidos em histórias, ou seja, em narrativas e, que isso, ele vai não só falar da nossa própria sociedade, como na visita à torre de Londres, mas também quando está diante de uma canoa trobriandesa ou de um colar, ou de um bracelete trobriandês ou diante daquelas moedas enormes, sem funcionalidade, praticidade, mas que tornavam possível evocar narrativas, histórias, relatos que tornavam acessível o significado daqueles objetos que, de outra maneira, permaneceriam absolutamente fora da consideração do antropólogo ou do visitante, porque na realidade se tratava de uma dimensão de algo não visível, cultura imaterial.

Malinowski, no capítulo sobre a canoa, é muito claro sobre isso, magnificamente claro. Como, para quem entende, um pingo é letra, não precisava dizer de onde retirava tais discussões porque eram discussões absolutamente clássicas do ponto de vista de quando um objeto deve figurar numa descrição. Uma questão levantada por mim, mas também uma questão colocada com todas as letras por Lessing, refletindo sobre Homero e todas essas questões que vão muito além do objeto em sua materialidade. O que os alemães chamam de "coisa para", objeto com uma teleologia, dimensão e propósito que atualiza o artifício humano, construção, habilidade.

Para a Antropologia, tudo que está fora da etnografia são considerações filosofantes que afastam o antropólogo da área em pode ter competência, proficiência face a seus colegas filósofos, psicólogos, analistas e cientistas políticos. Estes são marcadamente normativistas. Talvez o grande problema dos antropólogos sejam os cientistas políticos porque não é só aquela história de "conta a sua história e eu conto a minha história", como aconteceu um episódio famoso entre um colega nosso e uma colega, a respeito de reduzir a etnografia a "conte sua história que eu conto a minha" como se fosse reduzir a Antropologia a esse tipo de questão. Agora, obviamente, isso não quer dizer que a 
Antropologia, em sua dimensão etnográfica, que quer dizer muitas coisas e acaba não significando nada em certos contextos porque, ou se reduz à dimensão descritiva, quando sabemos não haver descrição sem teoria da descrição. A famosa questão levantada por Karl Popper. Um professor que entrasse numa sala e dissesse para seus alunos "descrevam!". Os alunos perguntariam: "descreva o quê?" Faço uma caricatura porque Malinowski não era destituído de formação para que não pensasse essas questões, quer dizer, não que ele não tivesse feito um exercício... sobre a guerra, por exemplo. Ele escreveu um livro sobre a guerra, nunca mencionado. Não sei porque nunca se menciona aquilo também, mas e teria variado nas suas atividades porque... a gente diz que Malinowski quando ele pensava em primitivo ele só vi um trobriandês, mas que trobriandeses que ele nos trouxe, né! Que trobriandeses tão assemelhados nas paixões que caracterizam uma boa parte da tradição intelectual do ocidente e que imaginação para tratar de fenômenos tão difundidos numa área tão ampla. Esse polonês foi capaz de mobilizar e tornar em escritos num texto, um texto belíssimo e que ele já de saída nos conduz a pensar exatamente sobre o seu objeto, o lugar e o modo como ele vai tratar esse objeto, esse lugar, esse fenômeno das trocas. Mas ele diz, inclusive, que ele vai usar... é um relato, account, é um relato, é uma narrativa, é uma história, é um prestar de contas de alguma coisa, é contabilizar essas implicações que o termo account suscita em inglês e que remetem sempre para ideia dos radicais, para a ideia de narrativa, de relato. Relato deriva de um verbo regular latino com implicações de algo que transcorre, se desdobra, ação, relato, narrativa, história. Esse hist - de história remete à narrativa, a algo visto por alguém, testemunhado. "Visto" não com os olhos apenas, mas que traduz experiência e, por traduzir experiência precisa encontrar sua forma narrativa. Para que essa experiência seja elaborada, é preciso encontrar a forma narrativa adequada. Existe algo que você atravessou, a que você se submeteu, voluntária ou involuntariamente, pouco importa. O que importa é que você atravessou-experience - de atravessar, a ideia de experiência. Então, a ideia de que você faz isso com seu próprio corpo. Essa dimensão aparece se você não tiver má vontade com Malinowski, não ficar procurando nele seu materialismo mecanicista, suas teorias da cultura, seus excessos marcados por certo positivismo de época. Deve-se qualificar tal positivismo, senão... qual deles? Ao mesmo tempo, com boa vontade de reconhecer, a capacidade de dizer para nós mesmos antropólogos, que o afastamento dessa dimensão empírica do trabalho, da descrição, ou seja, da etnografia, perdemos força, os argumentos perdem 
força. Conhecendo Turner e a vivacidade da sua disposição em relação à pesquisa de campo, complementou essa ideia, porque o Turner gostava muito de um personagem da mitologia chamado Anteu, um gigante. Enorme e fortíssimo, como os gigantes mitológicos, luta com Hércules que nota que sempre que Anteu tirava um dos pés do chão, enfraquecia, mas recolocava o pé no chão, saía mais revigorado e forte. Quando Hércules consegue levantar os dois pés de Anteu do chão, este morre asfixiado. Turner usava o personagem pra dizer "Back to the Grassoots, quer dizer, volte para suas notas, para seu caderno de campo, para o que ancora sua questão no mundo, no caso específico, no mundo dos Ndembu, por exemplo, tal qual ele dedicou uma grande parte da sua produção. Produção que tem uma história. Não apenas do Rhodes-Livingstone Institute, mas de sua própria formação. Começou com história, literatura, a ideia de drama, de dramaturgia, também um problema de ação. Ele tem uma inflexão muito interessante. Claro que marcada pelas coisas lá de Manchester, aquela coisa do Dezoito Brumário e a História, processo, algo que transcorre, se desenrola, com momentos, estágios, etapas. Esses momentos implicam em diferentes princípios evocados. O conflito, dimensão básica do laço social, que é a grande teoria alemã sobre o conflito. Enfim, a ideia de que é o conflito que produz o laço social. O contrário disso é a total evitação, o empobrecimento das relações, a incapacidade... é admitir que homens encarnam valores. Não há acordo sobre valores. Portanto, o tempo todo há uma dimensão importante a ser considerada no campo, inclusive no caso de nossa conversa, a controvérsia. O problema da controvérsia como dimensão importante que é trazida para Antropologia também.

Quando Malinowski chama atenção para essas questões na introdução e em seu livro principal, Argonautas do Pacífico Ocidental, está vinculado a uma tradição intelectual do ocidente que ganha dimensão importante no século XVIII, na poesia com Novalis, ou seja, com aquele pessoal do século XIX, século XVIII ao qual está referido. Um dos problemas importantes desse debate que vai aparecer em muitos outros momentos, não só na sua produção, mas na produção da Antropologia é exatamente essa combinação entre a descrição e a narrativa. Se a etnografia for apenas descrição, se fosse entendida assim (eu não entendo quem entenda assim, Hélio). Eu não conheço. Eu não conheço nenhum sociólogo que essencializou relações. Não vi Weber fazer isso, nem Durkheim e nem Marx, mas a gente fala de coisas. Você atribuiu a quem? Quem é a pessoa que foi que disse isso? Então, se a etnografia é só descrição, se fosse possível pensar assim é de 
uma pobreza monumental, entendeu? Ela é um mundo sem qualidade, quer dizer, a Antropologia seria um descritivismo, um etnografismo que acontece. Nós temos vários exemplos na Antropologia brasileira de etnografismo. Por educação, por amizade, não mencionarei o nome dos autores, famosos inclusive, que escreveram livros importantes e incompreensíveis porque são fruto disso que estou chamando de etnografismo. Um descritivismo sem propósito que no final das contas você não sabe o que a pessoa está falando. Você não vê nada, aquilo não te ajuda nada e isso não existe só no Brasil não. Isso existe na etnografia francesa, existe na etnografia portuguesa, existe... enfim, pra falar só de umas mais perto assim da nossa tradição ibérica, mas existe. Então, se é pura descrição, se isso fosse possível porque não é possível, seria um mundo sem qualidade. É o que o Georg Lukács em Narrar e Descrever, famoso ensaio que ele escreveu e passou desapercebido, a maioria dos antropólogos que eu conheço... nunca vi ninguém falar de Lukács e nem desse artigo porque ele ficou identificado, obviamente, com toda uma concepção da literatura, da escrita, mesmo da filosofia e do marxismo, que hoje em dia não está morto, mas que não é compartilhada pelo mesmo por uma parte da minha geração, por exemplo, na nossa geração. Mas Lukács escreve esse artigo exatamente em pleno período stalinista, meados da década de 30, em Moscou para fazer uma crítica ao realismo socialista. E vai chamar atenção recorrendo exatamente a esses autores os quais nós estávamos nos referindo anteriormente, entre Homero, claro e Lessing, ... o famoso texto desta oposição entre a pintura e a poesia e o problema de que se a pintura é capaz de representar a ação melhor que a poesia. Estou reduzindo é muito mais complexo do que isso, mas enfim as referências são as mesmas. O Lukács não está escondendo nada, ele está citando Lessing e está citando Homero em muitas passagens. Então, a grande questão do cetro de Agamenon e o cetro de Aquiles, quer dizer, o cetro de Agamenon e o cetro de Aquiles como ele é apresentado por Homero não é para ninguém fazer um cetro igual. Não é um trabalho de ergologia, não é um trabalho de ergologia como a minha amiga Berta Ribeiro se dedicou a fazer durante muito tempo, um trabalho necessário, fundamental do ponto de vista do estudo das técnicas, dos estudos dos museus, dos depósitos, né, os chamados "depósitos de etnografia" e que André Leroi-Gourhan dedicou praticamente toda sua vida, com pequenas problemáticas, incursões a outras áreas nas quais, no meu ponto de vista, ele não reunia as mesmas competências que ele reuniu em outros trabalhos que o notabilizaram como sistematizador do estudo dessas técnicas, tudo isso. 
Então, se é descrição, se alguém um dia achou que era só isso, isso não existe, isso é uma figura, coisa de retórica. Na realidade, etnografia literalmente significa descrição dos povos, notícia sobre povos, sobre raças. "Etno-" quer dizer uma porção de coisas também, inclusive escrever. Não só escrever, mas inscrever. Esse tema remete imediatamente à questão da escrita. Nós, antropólogos, parecemos não considerar necessário refletir sobre esse problema. Aí aparece Clifford Geertz, um neoevolucionista americano, depois convertido à sociologia alemã, como se ele estivesse se afastando da leitura... de Weber que ele tinha conhecido através de Talcott Parsons, o mesmo que aconteceu com Marshall Sahlins, outro neoevolucionista, junto com Elman Service, aquela turma toda vai fazer essa passagem para o estruturalismo, menos radical do que a passagem do Clifford Geertz, na minha opinião, porque ele quer combinar uma parte do marxismo dele com o estruturalismo. Mas é claro que é brilhante, importantíssimo. É uma referência. Qualquer coisa que eu dissesse ao contrário é uma bobagem, não faz sentido. Agora, eu acho que essa reflexão sobre o problema da escrita acabou levando dos anos 70 para cá, meados dos anos 70, a uma discussão do ponto de vista da etnografia que foi para literatura completamente. Foi para literatura completamente e foi para uma... chegando as coisas delirantes... e que você perde completamente a referência, e você usa argumentos para dizer isso. Você não pode identificar, então você estuda um lugar que não existe, pessoas que não existem e você mesmo não existe porque você se esconde através deste tipo de artifício literário de uma literatice para não problematizar sua própria posição como pesquisador e isso realmente é espantoso.

Eu uma vez estava numa reunião da ANPOCS e encontrei com vários colegas antropólogos. Estávamos falando e, de repente, eu achei que todo mundo... nós sabíamos o que nós queríamos dizer quando estávamos falando de dimensão etnográfica e foi um silêncio numa conversa, não era nenhuma mesa redonda era uma conversa em Caxambu. Ficou um silêncio e todos se entreolharam e as pessoas diziam "não, mas não há acordo sobre isso". Então têm etnografias virtuais, tem etnografia... qualquer coisa. Então, etnografia é uma palavra, um artefato que passou a ser usado por qualquer um. Os sociólogos franceses falam que eles estão fazendo etnografia. Como é que eles podem fazer etnografia?! Então, eu comecei a ver que era bobagem ficar discutindo o quê que era etnografia, o que não era etnografia. É melhor provar o movimento andando. Como fez o velho filósofo, aquela figura magnífica. Enquanto se discutia a 
impossibilidade do movimento, o homem andava de lá pra cá, sacaneando o colega. Então é melhor você fazer isso andando, ou seja, mostrando, não é demonstrando, mostrando. E desse ponto de vista o antropólogo, seja lá o que etnografia signifique, o antropólogo que desconheça os trabalhos de seus colegas sobre diferentes sociedades, diferentes grupos, tem uma formação pobre. Então, nesse caso, Mariza Peirano tem toda razão quando diz "antropólogo bem formado é o antropólogo etnograficamente bem informado". "Antropólogo bem formado é o antropólogo etnograficamente bem informado". Volta-se à questão dessas notícias, dessas descrições, desse imenso esforço diante da diferença, esse processo desse estranhamento, dessa reflexividade que não aconteceu agora. Está lá em Heródoto, você pode buscar onde você quiser na tradição intelectual do ocidente, sobretudo, do ponto de vista da Antropologia moderna e contemporânea associada pelo menos ao grande momento dos descobrimentos, século XIV, e essa revelação desse novo mundo e as implicações que isso vai ter sobretudo para o imaginário, para essa mudança de uma cosmovisão que terá consequências importantíssimas para nossa tradição intelectual. Não é à toa que Alexandre Koyré vai escrever um livro bonito, De um mundo fechado a um universo infinito, quer dizer, essas transformações que foram ocorrendo em termos das nossas, da nossa visão cosmológica. O mundo era muito diferente. Nossa concepção era geocêntrica, depois virou heliocêntrica, então você tem de um lado Ptolomeu que não era nenhum idiota, era um matemático sofisticadíssimo. Os cálculos de Ptolomeu são complicadíssimos! Muito mais complicados do que os cálculos que Copérnico que teve que fazer e Galileu porque ele tinha lá uma estante que Ptolomeu não tinha. Então, esse mundo né, e depois Galileu ainda vai dizer "tudo se move, está tudo se movendo". Isso tudo teve um efeito brutal, como chamou atenção Freud, sobre a nossa onipotência. Ele chamava de uma das feridas simbólicas. Eu acho que então a Antropologia, como disciplina acadêmica, ela começa na segunda metade do século XIX. Ela começa na segunda metade do século XIX já com essa oposição entre o trabalho de campo, que também não foi ela que inventou trabalho de campo, inclusive, e a teoria. Ou seja, essa oposição estereotipada entre o campo e o gabinete nunca foi aceita na Antropologia. Também eu não entendo da onde é que se tirou isso! Está na história da Antropologia, está nos livros dos nossos colegas, é uma coisa impressionante. Afirma-se e continua-se a afirmar que os evolucionistas não fizeram trabalho de campo. Isso é absolutamente falso. Os evolucionistas fizeram trabalho de campo, sim senhor! Estão aqui os cadernos de campo 
de Morgan e de The Indian Journals, 1859-1862. Está lá o trabalho de Tylor. Como que esse não é o problema! Agora, o Radon, na primeira história da Antropologia, na primeira tentativa de se fazer uma história da Antropologia, ele chama atenção de que esse trabalho entre o gabinete e o campo, eles são indissociáveis. Não há, não é possível ter essa Antropologia apenas com o material da coleta porque isso aí é um amontoado de coisas, não é isso? E se você... então, é interessante porque, você já pode localizar lá no Radon, já a ideia de um problema da escrita. Quer dizer, quando você vai fazer a escrita, a tal etnografia, como chama atenção Michel de Certeau na A Escrita da História, você vai estudar no seu gabinete, no seu gabinete cercado dos seus livros, dos seus mapas, dos seus dicionários, dos seus fichários para poder se debruçar então sobre suas notas de campo e as notas de outros que antecederam você. E atualizar essas experiências, a sua experiência através, uma experiência vicária. Você não estava lá. Quem chama atenção para isso é Florian Znanieck, The Method of Sociology, um livro da década de 30, início dos anos 30, essa tal da experiência vicária que é o negócio do Marcel Mauss, que o Dumont chama atenção porque ele falava como se estivesse lá "porque eu como, eu faço". Ele nunca fazia nada, ele nunca saiu de Paris! Foi ali, deu uma voltinha e voltou. Nunca fez trabalho de campo na vida dele. Neste sentido, o velho Durkheim também nunca fez trabalho de campo nesse sentido. Pelo contrário, quando usou dados usou dados estatísticos franceses e tal. Então, e, entretanto, se debruçou sobre pesquisas empíricas nesse sentido levantando questões a partir da pesquisa empírica que fizeram que o retorno ao campo ganhasse uma coisa fantástica. Então, o Clifford Geertz parece, quer dizer, a Antropologia não começou numa praia da Califórnia com dois alunos de Clifford Geertz andando de mãos dadas e conversando sobre a paisagem e a literatura. Não foi assim que começou. Tem muita água que já tinha passado de baixo desta ponte. E é preciso, eu acho que é preciso ver isso, ver materialmente o fetiche da pesquisa no livro. É preciso ver os alunos e os antropólogos que nunca fizeram isso, olhar e ver o que é Native Tribes of Central Australia. Eu preciso ver o que eles fizeram no final do século XIX, publicaram e ver.

Hélio Silva - De forma que em Mauss a relação necessária entre o gabinete e a etnografia está preservada apesar de não ter tido, pessoalmente, experiência etnográfica?

Marco Antonio - Acho que sim. Acho que, se entendi sua pergunta, ele mergulha nestes textos através de uma dimensão que, às vezes, o etnógrafo daquela sociedade não 
tinha: a dimensão comparativa. Chamava de sociologia comparativa o que RadcliffeBrown, amigo de Mauss, vai reproduzir também. Ideia que o acompanhou a vida toda. Está no famoso e lindo artigo de Merleau-Ponty De Mauss a Lévi-Strauss. MerleauPonty, citando Mauss, chama atenção de que se você fosse inventariar todas essas categorias ainda nos restaria "muitas luas mortas ou pálidas no firmamento da razão". É um projeto do racionalismo francês, mas de uma sofisticação e de uma capacidade de não perder a referência com o mundo que o homem comum também experimenta. Técnicas do corpo, forma do pão, quando estudou a distribuição dos celtas através do pão, lavar o rosto com água parada ou água corrente. É um exercício permanente de observação, de estranhamento, colocando em perspectiva, hábitos de sua própria sociedade. Mauss, embora não tenha se caracterizado por isso claramente, faz uma Antropologia de nós mesmos. Para usar expressão de George Perec, não mais o exótico, mas o endótico. Teve sensibilidade suficiente para fazer isso. Na ganga bruta daqueles dados, verdadeiras pérolas, tratando com o maior respeito. Malinowski, numa nota de pé de página em Crime e Costume, se não me engano, diz que Mauss fez teoria melhor que a dele. O que também é uma forma do Malinowski dizer: eu sou tão bom, a minha etnografia é tão boa que permite outro colega ir muito além do que eu fui, mas existe essa etnografia. Existe etnografia de Spencer e Gillen que permitiu a Durkheim dar uma virada na vida dele com as “Formas elementares da vida religiosa” em 1912.

Hélio Silva - Mello, permita que o interrompa. Ao mesmo tempo que você demonstra a impossibilidade em Ciências Sociais de uma observação desprovida de teoria, lembra também a dissociação em Malinowski entre teoria e observação.

Marco Antonio - Da vida... da observação.

Hélio Silva - Caso também de Euclides da Cunha. O relato de Euclides não se conforma às suas referências teóricas, sua visão de mundo. Sobra. Em Malinowski também... Você demonstra a impossibilidade de observação desgovernada.

Ela tem que ter uma orientação teórica. No caso do não-cientista social há referências de sua cultura que permite que ele discrimine, identifique particularidades do objeto e tal. Mas é curioso que, nos casos citados. Há dissociação, entre teoria e observação. Se não mistura alho com bugalho, essa dissociação está presente em "Os Sertões”. 
Marco Antonio - São poucos os textos teóricos de Malinowski. E são de um materialismo mecanicista absurdo. Na Teoria da Cultura, cultura é, como o cara da Sociobiologia "espuma na crista da onda no imenso oceano da Biologia". Epifenômeno do epifenômeno. Acho que, ao longo do seu trabalho, ele mudou esse ponto de vista. Conhecer Malinowski é conhecer suas monografias.

Hélio Silva - Mas Uma Teoria Científica da Cultura é posterior a Argonautas.

Marco Antonio - Mais que posterior, é póstuma. Artigos reunidos postumamente. É engraçado que Radcliffe-Brown publica nessa mesma época A Natural Science of Society, quer dizer, o Malinowski vai publicar esse conjunto, ele não, postumamente vão publicar esse texto dele, Uma Teoria Científica da Cultura, e em vida RadcliffeBrown vai publicar A Natural Science of Society, quer dizer, ele queria também fazer uma ciência natural da sociedade. Entretanto, também o Radcliffe-Brown também vai dizer coisas fantásticas, coisas inclusive que o Lévi-Strauss, em determinado momento, você tenderia achar que Radcliffe-Brown não teria contribuído para as questões levantadas por Lévi-Strauss depois sobre o totemismo, mas Huxley Memorial Lecture de 57, se eu não me engano, do Radcliffe-Brown é extremamente importante sobre método comparativo, então ele falando destas questões. Então, essa tensão você vai ter, quer dizer, você fala de Euclides da Cunha. Euclides de Cunha tem esse modelo do século XIX que é o modelo de escrita da história é o modelo do Hippolyte Taine, o negócio do meio, a raça e o momento histórico, e que me permite falar de uma outra coisa a ideia de que... O Marcel Mauss chama atenção, naquele curso que ele deu, que depois seus alunos transformaram numa espécie de manual, que o que o ingleses chamam de Social Anthropology, os franceses distribuíram em duas disciplinas diferentes: Sociologia do Direito e Sociologia da Moral. O Marcel Mauss então com muita fineza, apreendeu o núcleo central, a obsessão da Antropologia social inglesa, a transformação da regra em valor. Rituais adquirem, não só por causa das sociedades que os ingleses estudaram, mas tema: como uma regra, externa, se transforma em valor, internalizado, o que remete a ação. Mauss entendeu essa oposição, importante porque remete à questão dos valores, costume, custom, modos de fazer. As expressões: "nosso costume aqui é fazer assim, "o costume aqui é esse". Na realidade, fala-se de modos de fazer, formas ritualizadas. Tema importante na Antropologia Política. Surgem algumas questões, por exemplo, a ideia de drama social do Turner. E na discussão sobre drama 
social, talvez por uma dificuldade da língua inglesa, assim como também um problema da língua francesa, não se faz uma distinção muito clara entre evento e acontecimento. Numa entrevista de Lévi-Strauss, o entrevistador indaga sobre o problema do evento, do acontecimento e da estrutura e Lévi-Strauss fala o tempo todo de événement, claro. É difícil compreender a ideia de Social Drama, talvez mais difícil, quando você não tem essa distinção entre evento e acontecimento como nós temos em português e espanhol porque o evento não se organiza, não se estrutura. O evento é aquilo que se abate sobre você, é o que vem sobre você. Então, nós temos a distinção entre o evento e o acontecimento, ou seja, o acontecimento é o evento mediatizado pela linguagem. $\mathrm{Ou}$ seja, voltamos ao problema da experiência, o problema da narrativa. Então, essa distinção vai ser muito importante porque na Antropologia contemporânea, já tem Ilhas da História, esses livros do Marshall Sahlins onde há uma distinção entre acontecimento, estrutura, evento e estrutura. Mas esta distinção, me parece que às vezes não é bem esclarecida deste ponto de vista. Isso também é um problema porque você vê, você estava falando de Euclides da Cunha. Você tem uma coisa que é a guerra que ele vai como repórter. Ele vai exatamente achando que é uma coisa monarquista contra a República. Ele é um republicano. Não sou um conhecedor de Euclides da Cunha, mas é como se fosse uma reconversão, uma conversão ao longo de um trajeto, de um percurso, de um caminho. E que ele vai colocando em perspectiva os autores que, na realidade, talvez em outro momento da sua vida e da sua produção tivessem... pudessem tê-lo conduzido para um caminho completamente diferente.

Hélio Silva - Esse tipo de conversão tem certa frequência em experiências etnográficas...

Marco Antonio - Claro! Mas isso Malinowski diz na introdução dos Argonautas do Pacífico Ocidental, ele diz claramente, inclusive, citando famoso texto sem dizer o autor, texto para o qual, aliás, Rubem Alves, em seu livro sobre filosofia da ciência, chama atenção e cita. Fala inclusive das redes. Não adianta o antropólogo chegar lá e arrumar uma rede, não vai pegar nada. Depois ele fala do etnógrafo como caçador alerta. O caçador alerta é uma figura de Platão... O etnógrafo, o trabalho de campo, várias questões teórico-metodológicas importantes.

Ele não recolheu isso de outro lugar pra fazer essa reflexão. O que ficou foi aquela pobreza da teoria dele da cultura. Então, eu acho que seria... nós tivemos tanta 
generosidade com autores, pelo menos a nossa geração, como Marx, por exemplo, que falou de raça. Esqueceram tudo isso. Todos os problemas deterministas que existem em Marx. Toda teoria epifenomênica do mundo, chamada superestrutura que está lá na Ideologia Alemã e outros textos. Fomos condescendentes. Os antropólogos frequentemente, como por exemplo Evans-Pritchard, são marcados por um verdadeiro ressentimento em relação a Malinowski. Ele foi aluno de Malinowski. O Adam Kuper, disse para ele em Paris, numa conferência que fez na René Descartes: por que em Antropólogos e Antropologia o único autor ao qual reserva certa ironia é Malinowski?

O diário de campo, né, From Native Points of view do Clifford Geertz que ele começa fazendo uma reflexão sobre a publicação do diário de campo. É como se fosse "ah! coitado! Ele então não era aquele milagre ambulante de empatia, cosmopolitismo, sintonia com o ambiente", nunca foi! Mas nunca foi! Então, ao contrário, a revelação da indiscrição feita por sua viúva, Raymond Firth não gostou muito e chegou a censurar no sentido... Isso aqui não tem relevância nenhuma para Antropologia, você vai publicar isso pra quê? Certas partes do diário, o diário é enorme! Você já viu o diário todo?

\section{Hélio Silva - Não.}

Marco Antonio - É imenso. Estava procurando uma livraria polonesa em Paris e descobri que Anne Roland, sobrinha de Lévi Strauss, professora titular em Paris 10, me disse que estava procurando também porque eu estava interessado naquilo. Eu falei a razão. Em polonês tem uma introdução bem-feita e eu queria encontrar uma amiga que me ajudasse a ler algumas coisas. Ela também estava com um amigo ajudando ela a ler um troço enorme. Eu perguntei por que e ela disse "não, porque meu avô era comerciante de pérolas nas ilhas Trobriands e conheceu Malinowski”. Eu queria ver se Malinowski fala dele no diário. Ela estava com essa preocupação.

Hélio Silva - Quando você acha que...

Marco Antonio - O Malinowski está refletindo sobre isso. Chama atenção para que é inútil ir a campo (o que Evans Pritchard também diz depois) para ilustrar teorias preconcebidas. Se já se sabe tudo, pode-se deduzir. Embora indispensáveis, não adiantam apenas teorias. Teorias são redes, digamos assim, mas dependem do que você está querendo fazer. Então, ele está sempre chamando atenção para isso e, ainda dizendo com todas as letras, nosso lugar é com outro branco, europeu. Branco é uma metáfora 
para falar da sociedade europeia porque é realmente um problema. Estava no alto Xingu sentado num banco em frente à casa das flautas, olhando aquele céu magnífico, um índio ao meu lado, me perguntava: “estou olhando o mesmo céu dele?” Ele está fluindo essa contemplação estética na qual fui socializado para contemplar? Contemplar e me produzir um sentimento de beleza. Aquilo não tem montanha, não tem nada, aquilo é incrível. Isso é uma coisa. Agora, outra experiência também no Xingu, os índios botando a mão em cima de mim e tal, depois me abraçando e dizendo assim "você, nós gostamos muito de você", mas por quê? "porque você não tira a mão, a gente bota a mão no seu ombro e você não tira a mão". Eu levava as crianças para dormir quando estava chovendo na floresta. Então você também leva coisas, existe uma coisa que é universal que é apreensível em qualquer sociedade e em qualquer circunstância, que são essas coisas que o Lévi-Strauss acha que... são a dimensão dos afetos que podem aparecer travestidas de diferentes formas, mas elas, a ação relacionada ao seu gesto, quer dizer a ação, a compreensão relacionada ao seu gesto em certas circunstâncias ela leva você a isso. Então, eu acho que seria pouco, seria muito pouco generoso com Malinowski, a magia dos jardins. Depois que Reo Fortune vai fazer lá em $O s$ Feiticeiros de Dobu os argumentos contrafactuais. Então essas coisas, Hélio, a Antropologia não é aquela coisa que alguém "conta sua história que eu conto a minha história". Não é só uma fabulação, no sentido negativo do termo, não é só ficção no sentido negativo do termo, estereotipado, que foi interditado, como chama atenção Luiz Costa Lima que, aliás, foi muito importante com a indicação de um livro que era o livro de um holandês que escreveu em alemão que era o André Jolles, importantíssimo pra mim num momento da minha pesquisa de campo que foi a ideia de saga.

Felipe Veiga - Você foi a Campos em Zacarias, Maricá, diante de um evento que se abatia sobre o ambiente local, uma grande mortandade de peixes. Como é que a própria pesquisa de campo acabou levando você a considerar outras questões e a produzir um grande artefato da sua pesquisa que foi uma genealogia de parentesco em seis gerações? Como é que você, de questões ambientais dentro de um organismo, de um ministério, dentro de um organismo federal no Ministério da Agricultura, numa localidade do litoral fluminense, deixa de estar unicamente verificando essas questões imediatas do problema da pesca e acaba realizando um investimento desse tamanho na área da família e do parentesco local? 
Marco Antonio - Bom, em primeiro lugar, eu fui como antropólogo trabalhar nesse órgão que pertencia ao Ministério da Agricultura, a SUDEPE e, dentro da SUDEPE, havia o PESCART, Plano de Assistência à Pesca Artesanal. Eu, Roberto Kant de Lima e Elina da Fonte Peçanha. Eu era, ou seja, quando eu fui para o campo trabalhar, eu fui trabalhar numa coisa que eu construí. Não existia esse PESCART-RJ, esse PERCARTRJ surgiu de uma conversa absolutamente inusitada entre dois professores, um de geografia e um de Antropologia. O professor de geografia perguntava para o antropólogo se Antropologia tinha alguma coisa a ver com pesca e ele disse que não, que achava que isso não tinha nada a ver com aquilo ali e não sei o quê, no sentido... Estou fazendo uma caricatura, não foi bem assim, mais ou menos. Eu passei uma primeira e comecei a falar que tinha tudo a ver porque eu tinha feito... eu tive bons professores na graduação, professores aos quais devo toda a minha formação como antropólogo, toda! Não é um pedaço não, toda a minha formação eu devo a dois professores especificamente, o professor Vagner Neves Rocha, que nunca escreveu um livro, nunca fez doutorado que escreveu uma dissertação de mestrado, nunca escreveu artigo. E professor Luiz de Castro Faria que também não se notabilizou entre os antropólogos brasileiros porque não escrevia obras, escrevia artigos, inventários e foi um ator importante. Eu tinha feito cursos sobre estudos de comunidade, que era uma Antropologia, uma velha moda da Antropologia como chamava atenção Castro. Mas que era imprescindível se debruçar sobre os estudos de comunidade, não só para discutir questões teórico-metodológicas sobre seu alcance, limites, tudo isso, mas também para você ter na sala de aula era um curso praticamente noturno. $\mathrm{O}$ acesso por pessoas interpostas, há áreas do Brasil e fora do Brasil que haviam sido submetidas a pesquisa empírica de campo, a pesquisa, estudos muitas vezes voltados para a Sociologia do Desenvolvimento porque não pode esquecer que nos anos 50, sobretudo, os anos 50 e 60, logo no pós-guerra são anos marcados por um conjunto de teorias sobre a mudança social dirigida e que vai envolver sociólogos, antropólogos e todo mundo. Os grandes projetos, sobretudo, no contexto da guerra fria que você vai ter então uma série de iniciativas e a proliferação desses estudos, estudos inclusive para vender privada, para saber se os caras tinham privada, se não têm privada. No final das contas, sua dimensão era muito objetiva. No caso do PESCART, o geógrafo não imaginava que ia transformar aquele troço que ele tinha dado um jeito, em arranjar um jeito de conseguir recurso do PIM E PROTERRA cursos apenas no Norte e Nordeste para trazer para o sudeste por 
relações de família. Ele não podia imaginar, aliás, ninguém poderia imaginar no que deu esse encontro fatídico com o antropólogo dentro de um fusca, que era um carro maravilhoso da época, banco traseiro...

Hélio Silva - Maravilhoso até hoje.

Marco Antonio - E um outro antropólogo, que naquela época era um vendedor de títulos da bolsa de valores, um homem muito bem-comportado, barba muito bem-feita, terno de tergal, gravata, camisa de tergal, relógio no pulso e pasta James Bond, que era o professor Roberto Kant de Lima, que não tinha tempo para continuar aquela conversa dentro do carro espremido, teve que saltar e dizer assim "garante essa conversa aí pra gente". Saltei e continuei falando. Falei igual uma matraca. Saltamos do carro e fomos para casa do Wagner de Rocha e continuei a conversa. Dario Castelo, que era o geógrafo, foi embora e continuei tentando converter meu amigo e professor de que aquilo valia a pena e de que era importante. Falei tudo que podia falar sobre Antropologia, pesca, vários problemas. E esse projeto que na realidade tinha um objetivo muito assistencialista. Havia no Ministério da Cultura um debate entre sindicalistas e cooperativistas. Um grupo queria fundar a cooperativa. "Brasileiro não é solidário", "não se associa pra nada", aquele papo todo do século XIX. Entendeu? E o sindicalismo era um debate. Então, nós fomos trabalhar naquilo e eu não tinha a menor experiência de conviver com o Estado. Eu não sabia o que era um Secretário de Agricultura. Eu tive bate-boca com o Secretário de Agricultura no corredor. Todo mundo ficava olhando apavorado porque eu não entendia o que era aquilo, não entendia essas hierarquias. Alguém dizia que tinha que reunir os pescadores e que ele ia fundar uma cooperativa e eu disse "você vai montar uma cooperativa como e tal?" Depois fui com Matta, um ano depois, dois anos, e Roberto Kant de Lima também, ao IMPE, Instituto Nacional de Pesquisa Espaciais. Chegando lá tinha o Inostrosa, eu nunca esqueci o nome desse cara, que dizia que tinha que abrir a cabeça dos pescadores pra ensinar aquelas coisas. Perguntei pra ele: "você vai abrir como? Com uma machadinha? Foi uma confusão danada no INPE, no seminário. Quer dizer, esse etnocentrismo, esses estereótipos, isso tudo era pervasivo, estava em tudo quanto é lugar, na universidade também. A mulher do Presidente da Assembleia Legislativa, que era presidente da ARENA, professora da Faculdade de Serviço Social deu uma entrevista aos jornais. Na mesma época ela foi trabalhar, ela foi embora. A entrevista era assim "curtidos pelo sol 
e pela cachaça o pescador fluminense". Era tudo assim, entendeu? Era uma loucura! Os caras diziam assim, o senhor sabe né professor, os pescadores, eles não querem fazer nada. Eles não se associam pra nada. Eles se juntam para trabalhar e depois se separam e não se associam. Eles se juntam pra trabalhar e depois se separam, ele fazia esse gesto com a mão. Eu dizia quer dizer então que eles se juntam para trabalhar, mas não se associam pra nada e depois separam, igual a gente. Nós estamos aqui juntos para trabalhar e depois cada um vai pra sua casa fazer suas coisas. Então era complicadíssimo trabalhar no Ministério de Agricultura na Secretaria de Agricultura que era um lugar que tinha boi. Só se pensava em boi Nelore, Gir, Zebu, só se pensava nisso. Os veterinários, os agrônomos não tinham que saber de pescador. Pescador não tinha importância nenhuma. Até hoje não tem estatística de pesca no Brasil. É uma coisa horrorosa, então você não tem como planejar nada e fazer nada. E nós fomos pra lá e eu fiquei... eu e Kant começamos a escrever a justificativa desse projeto. Só que a justificativa era interminável, até que um dia a mulher de Kant levantou de madrugada e disse: "vocês não vão terminar a justificativa nunca." Eu de cueca, Kant de cueca tomando "cachorro louco" que era um copo de cachaça com limão...

Hélio Silva - Ah! Eu sei, eu sei.

Marco Antonio - E aí nós falamos, a gente cheio de papel, "mas como não vai terminar?". Vocês escreveram tudo! Vocês escreveram a justificativa, o projeto, o subprojeto, escreveram tudo. Aí nós olhamos um para o outro, aquela pilha de papel, que redundou nisso aqui que foi feito em 74 para ser aplicado em 75. Quando nós fomos levar à Brasília é que eu conheci a Mariza Peirano. Esse órgão financiou a pesquisa de Mariza Peirano e o Túlio Pérsio Maranhão também no Ceará. E o Gari dizia para os caras em Brasília "eu também tenho os meus antropólogos", aí um mostrava assim, está entendendo? Porque tinha uns antropólogos em Brasília. Então nós fomos trabalhar nessa história e um dia, nós estávamos montando o programa e houve uma grande mortandade de peixes. Duzentos e cinquenta toneladas de peixe podre em Maricá. Eu nunca tinha ido à Maricá a não ser uma vez, duas vezes na minha infância porque papai tinha um terreno em Maricá. E nós íamos num jipe velho, de vez em quando, para terror meu e das minhas irmãs irmos ver o terreno, uma coisa que eu só fui entender quando já fazendo etnografia em Zacarias. Só fui entender isso muito tempo depois. Então, eles iam ver o terreno e era uma loucura aquela coisa de ver o terreno. Chegava lá não tinha 
nada. Não tinha nada! Tinha um terreno e tinha um cara, aí mamãe limpava uns pedaços, quebrava uns galhos podres quebrava umas coisas de umas árvores limpava o chão. Papai jogava uns galhos pra lá e tal, e conversando com os caras que moravam por ali e tal, depois voltávamos. Era um tédio! Pior coisa que tinha pra nós era quando papai e mamãe resolviam ver o terreno em Maricá. [Risos]

Porra era um troço de louco. Só tinha eu, minha irmã abaixo de mim, meus irmãos gêmeos já eram nascidos, né, meu irmão e minha irmã. Era uma coisa horrorosa, um jipe da época da guerra. E uma outra vez eu fui com papai pra caçar. Eu achava que ele ia caçar comigo e pescar, mas na realidade ele ia encontrar os amigos dele pra comer camarão, siri, beber, conversar, contar história e tal. Eu ficava sozinho lá e achava chato, achava que papai ia caçar comigo. Papai caçava comigo, mas quando ia à Maricá ele encontrava os amigos dele, coisa também que eu demorei muitos anos a entender sobre a sociabilidade masculina. Porque as crianças têm muitos problemas com isso porque a visão da criança é uma visão feminina dos espaços masculinos. Eu também só fui entender quando fui estudar o Catumbi e botequim no Catumbi, embora eu fosse frequentador de botequim, eu nunca tinha entendido... na realidade eu não sabia o que era um botequim. Só fui saber o que era um botequim estudando o Catumbi em 1979. Já era um homem, já tinha escrito..., mas então e fui então à Maricá. Isso eu era criança, aí fui à Maricá esse dia. Cheguei lá tinha peixe podre pra burro. O quê que era Maricá? Não tinha nem um mapa! Então eu fui, comecei a puxar um papo com os pescadores, todo mundo na beira da lagoa eu comecei a desenhar. Fingi que sabia desenhar a lagoa na areia assim no chão, não na areia da praia..., Mas e aí o pescador pegou e começou a desenhar a lagoa toda pra mim. Kant em pé olhando. E ele foi então... nós fomos ali então localizando onde estavam os povoados porque eu precisava distribuir alimentos e Elina não tinha ido. Elina iria se encarregar de fazer a ficha da quantidade de cada coisa para cada grupo doméstico. Mas eu precisava saber onde estavam, quantos eram e como é que tinha acesso aquilo. Então, fizemos aquilo ali rapidamente, distribuímos os técnicos todos. Renato Lessa trabalhava nesse troço como estagiário também. E eu ouvindo aquelas pessoas falando na lagoa resolvi fazer um... dar uma andada com Kant como motorista do fusquinha do órgão que eu trabalhava. Fomos até Barra de Maricá. Chegamos lá os pescadores estavam praticamente... tinha pescador chorando e eles falavam da barra porque alagou, porque tem que abrir essa barra, porque essa barra... enfim, uma história que pra mim me marcou muito. E na hora eu tive uma intuição que, 
não quer dizer nada, mas uma intuição no sentido próprio do termo literal, quer dizer, um mergulho pra dentro de alguma coisa e eu achei que aquilo ali era um ritual. Essa abertura da barra é um ritual, ritual, pra quê? Antropólogo também acha ritual em tudo quanto é lugar. Tudo conversa fiada tem ritual para tudo quanto é lugar. Então eu fiquei com esse negócio na cabeça e abandonei aquela história. Tinha referências, li sobre isso e Kant estudava umbanda, depois passou a estudar Sociologia da Medicina. E ele conversava muito comigo e um dia eu falei "vem cá, cara. Você não gosta de praia não, Kant? Você não gosta de sol, peixe, praia? Por que você não estuda Itaipu?" porque eu estudava Itaipu. Eu não estudava Maricá estudava Itaipu. "Por que não estuda Itaipu?" "Então hein pô, eu nasci em Copacabana fui criado em Tubarão então eu gosto de praia. Por que não estuda em Itaipu? É muito mais legal e tal". E eu fui estudar Maricá, quer dizer, larguei Itaipu pra lá, quer dizer, continuei conversando com ele, discutindo e comecei a pensar em estudar Maricá que era uma área do interesse do Castro Faria que tinha estudado, nos anos 40, a Lagoa Feia, também largou pra lá. Eu pensei em estudar só que não apareceu oportunidade. Entrei para o Museu para fazer o mestrado. Entrei para o museu para estudar sociedades camponesas. Entrei no Museu para estudar isso, Sociologia Econômica, Sociedades Camponesas, mas eu não conhecia as pessoas. Resolvi fazer um tour no Museu como aluno para saber o que os professores faziam de pesquisa para saber para onde é que eu ia, o que eu ia fazer. E a primeira pessoa que eu entrei na sala estava assim em pé conversando comigo foi Anthony Seeger. O que ele fez? Ele disse para mim: você não quer ir pro Xingu? Eu fui surpreendido com uma coisa assim que eu nunca tinha pensado em ir pro Xingu. Ele falou e tal, acabei indo pro Xingu. Eu não vou me estender sobre isso. Naquela época os índios Waurá ou Wauja, como eles se autodenominavam, tinham poucos falantes em português e tinha basicamente um falante assim Atamai. Eu fui pro Xingu para estudar ritual e economia, meu objetivo era esse. Para mim tanto fazia estudar os Waurá, quanto os Kalapalo ou Urus, tanto fazia. Mas ninguém tinha ido para o Waurá na época. Então como os antropólogos são muito ciosos de seus grupos, embora eles digam que não, eles acham que são donos dos grupos e eu tive essa experiência em várias situações. E eu fui, acabei indo, não era os Waurá que eu ia inicialmente, mas acabei indo para o Waurá porque não tinha ninguém, então eu fui. Depois da segunda viagem ao campo, eu estava com tudo preparado para fazer o que seria uma dissertação de mestrado e me surpreendi com a incapacidade do meu orientador na época, o professor Anthony Seeger de ouvir um 
estudante e de considerar as questões que o estudante estava trazendo como sendo questões relevantes e tal. Ele tinha lá as ideias dele, que eu não sei até hoje quais são e que, se eu não fizesse aquilo daquele jeito porque eu também não sabia o que ele queria, não adiantava eu ir. Ele já tinha tido esse episódio anterior comigo que eu já tinha idealizado Malinowski. Eu fui mostrei para ele que não era nada disso. Ele disse que Malinowski nunca tinha escrito aquilo. Eu falei escreveu sim, está na página tal. "Não, mas eu não tenho", aí eu estava nessa página aqui e tal sobre cultura isso que está aqui. Ele foi levantou foi no fichário dele mudou a ficha sem nenhum problema: "ah muito obrigado, eu já li isso tantas vezes e nunca prestei atenção nisso". Pois é, ele mudou a nota do meu trabalho. Ele era uma pessoa que todo mundo gostava e tal. Acho que todo mundo gostava, mas eu tive um problema grave com ele porque ele queria que eu fizesse a dissertação com o que eu tinha. Eu disse não, mas agora é que eu vou voltar para o campo. Eu tinha tempo, naquela época nós tínhamos tempo pra fazer trabalho de campo e escrever.

Hélio Silva - Cinco anos, né?

Marco Antonio - É... mas não tinha isso. Eu não tinha esse tempo todo. "Ah não, mas você tem que fazer isso". Aí eu falei não vou fazer. Se é pra fazer isso pra eu ir pra lá com que eu tenho aqui e ficar escrevendo aqui, não, não dá. Então eu tive a felicidade de me encontrar com um aluno, ex-aluno, na rua São José. Ele disse pra mim, a primeira pergunta que ele fez foi se eu entendia de etnografia. Olha, eu disse eu acho que alguma coisa eu devo entender porque eu fui seu professor, mas por que? "Não é porque eu estou num projeto na Secretaria de Agricultura do Estado, departamento, que é sobre negócio de pescadores e tal. Eu vou arranjar pra você um trabalho". Porque eu estava sem fazer coisa nenhuma, tinha vindo do Xingu, meio assim. Tinha sido cassado na UFF, eu fui cassado em abril de 77 e impossibilitado de continuar a dar aula. Tinha pedido demissão do PESCART em 76. Por quê? Porque eu tinha que preencher com o Kant, de quinze em quinze dias, uma ficha do departamento de segurança de informações. Ou seja, o lugar do pesquisador num aparelho de Estado é zero, porque aparelho do Estado não é lugar de pesquisa. Castro Faria tinha chamado atenção para isso. Então era um lugar para você executar uma política. E quando no Estado você começa a mandar pessoas fazerem coisas para ontem, urgentemente, afastando você do seu objetivo principal é que alguma coisa eles estão dizendo pra você. Eles não querem 
que você faça aquilo. Então, eles têm várias coisas. Ou eles fazem essas manobras ou eles promovem você. Então a promoção era eu ir para Brasília. O Kant para o organismo central em Brasília. Eu não tinha condição de ir pra Brasília e aquele constrangimento, eu resolvi pedir demissão. Pedi e, no mesmo momento Kant também pediu, questão de horas depois, Elina, mas Elina era cedida da Secretaria de Educação, porque ela era professora, para Secretaria de Agricultura. Então, ela voltou para secretaria. Eu não, eu me demiti.

Então, esperei, tem a ver com Luiz Eduardo Soares que eu vou te dizer. Esperei, esperei, esperei, uma semana, nada do cara me procurar. Aí eu tomei a iniciativa, que eu nunca tinha feito, ir sozinho no lugar e me apresentar dizendo eu sou uma pessoa que quero fazer isso que vocês estão dizendo que vão fazer. Aí a pessoa ficou muito atrapalhada daqui a pouco eu me lembro dela - depois ela fez dissertação no Museu. Era uma folclorista, aí ela falou assim "mas tem que ter um projeto". Eu falei a senhora tem um papel aí? Qual é o.... é sobre o que o assunto? Aí eu escrevi.

Felipe Veiga - Cássia Frade

Marco Antonio - Cássia Frade. Eu fui escrever na frente dela um projeto num papel. Escrevi à mão. Fui escrevendo, escrevendo, coloquei a bibliografia e coloquei tudo ali para ela. Ela ficou olhando para mim espantada, não acreditava. A Secretaria de Agricultura... era um projeto sobre tabus, crendices e superstições dos pescadores. Eu obviamente que não ia estudar tabus, crendices e superstições de pescadores e escrevi outro troço. E esse outro troço falava de conhecimento naturalístico e falava ta ta ta ta. Uma semana depois recebi um telefonema. Foi aprovado o projeto e eu ia para o campo. Mas aí esse meu ex-aluno estava ali do meu lado. Hoje é uma figura proeminente lá no Mapiá, lá na Amazônia, um grande líder do negócio, como é o nome?

Felipe Veiga - Santo Daime.

Marco Antonio - Santo Daime. Dizia para Rubem César durante o curso "o coiso" e aí o pessoal dizia assim: "o coiso, que coiso?". Foi num seminário no Museu. Ele foi aluno do Museu. O "coiso" que "coiso?", ninguém sabia o que era "o coiso" que ele estava falando. O "coiso" às vezes era Evans Pritchard [Risos] ninguém sabia quem era. Esse camarada, aí a mulher me apresentou ele e disse assim: Então olha, como o senhor é... o senhor vai, ele vai com o senhor pro campo, então o senhor vai orientando ele. Aí eu 
perguntei, nunca perguntei isso na minha vida, eu perguntei pela primeira vez e nunca mais pergunto: e quanto eu vou ganhar e quanto ele vai ganhar? Aí ela disse pra mim que era a mesma coisa. Então eu não vou orientar nada ele no campo, cada um vai fazer uma coisa e eu vou para Maricá. Aí marquei com ele, sei lá, cinco horas da manhã pra gente ir de ônibus pra Maricá, ele apareceu nove e o pior é que eu esperei. Fiquei sentando na rodoviária e ele uma confusão danada. Chegamos em Maricá ele falou: "estou doido..." quando estávamos na rodoviária ele disse: "estou doido pra chegar no campo" e eu disse, mas eu já estou no campo. Eu já estou aqui tomando nota sobre a rodoviária, quem é que entra nesse ônibus, percurso que vai ser feito, já estou no campo. Aí chegamos em Maricá ele falou assim: "como é que nós vamos fazer e tal?" Eu falei, eu vou para o mercado de peixe. Supostamente é onde vai ter pescador, né? Peixe e pescador deve ter no mercado de Peixe. [Risos] Eu fui pro mercado de peixe. Cheguei no mercado de peixes comecei a conversar e o cara foi e falou: "esse senhor aqui é de lá, seu Poeira". E tinha um velhinho, logo depois a gente chamou de um homem anzol, né, todo curvado, chapeuzinho, seu Henrique: "Ah, eu moro no Zacarias, tal, pode passar lá amanhã ou hoje" sei lá o que. "Chega lá e tal no meu rancho".

Hélio Silva - O pescador?

Marco Antonio - Pescador. Ele de carro, carrinho de mão de madeira que ele empurrava. Aí no dia seguinte eu fui pra lá e esse rapaz foi para outro lugar em Maricá. Ele devia ir para Saquarema, mas ele foi colado em mim. Aí cheguei nesse lugar, Zacarias, de ônibus velho e fui pela beira da praia fui encontrar esse pescador no rancho de pesca de canoa, rede. Eu passei então quinze dias nesse rancho de pesca que foram decisivos para responder a sua pergunta e que me fizeram então considerar pela primeira vez a pesca lacustre, Maricá e Zacarias como um grande objeto de pesquisa. E nessas conversas com o Henrique, essas conversas elas eram muito variadas, né? Sobre tempo, sobre lua, sobre maré, sobre pássaros, sobre restingas, sobre... enfim, aparecia também uma relação enorme com problemas associados a um personagem que era chamado Juca Tomás. Ou seja, as referências de parentesco eram de tal ordem nas conversas e nas conversas com qualquer um depois. Eu comecei a ter que fazer uma genealogia de qualquer coisa para poder entender o que eles estavam falando. Inicialmente eu não tinha pensado em me ocupar das relações familiares e parentesco. Eu tinha pensado que uma colega, que era minha mulher na época pudesse fazer sua 
dissertação no IFCS em sociologia, mas na perspectiva da Antropologia sobre essa coisa da família e tal. Mas acabei tendo que me ocupar porque ela mesma não se ocupou depois e eu acabei tendo que me debruçar sobre isso, não por nenhuma afetação de antropólogo achando que tinha obrigação como antropólogo de dar um exemplo de algum tipo de habilidade para fazer uma genealogia de parentesco, né, porque Edmund Leach, num daqueles volumes da ASA, Rethinking, chama a atenção para esse problema. Não há lugar nenhum e nenhuma formação em Antropologia em que esse campo de parentesco esteja ausente. Todo mundo é obrigado a falar alguma coisa sobre parentesco fazer alguma genealogia, como se esse campo fosse definitivamente estabelecido, com alta formalização e que não houvesse nenhum problema. Ninguém sabe o que é incesto direito. Leach coloca isso muito claramente, sempre mostrando diferentes sociedades e diferentes questões. Pode o Lévi-Strauss dizer tudo o que ele quisesse dizer depois, não é? Porque Leach foi o grande crítico do Lévi-Strauss. Depois o Needham que acabou formando um monte de estudante pra ficar no pé de LéviStrauss como a Francis, aquela argentina criticando tudo que Lévi-Strauss fez de errado em termos de parentesco, coisa que inclusive que ele nunca escondeu. Ele disse para Matta, inclusive, que era uma pena terem traduzido As estruturas elementares do parentesco. Era um livro errado então. Mas então eu fui fazer isso. Mas então eu fui para Maricá para estudar este problema do conhecimento naturalístico que foi sempre uma coisa que me chamou muito atenção. E que era o lugar que eu podia juntar Marcel Mauss, Lévi-Strauss, Radcliffe-Brown podia juntar todas as coisas da Antropologia porque na ideia de conhecimento naturalístico estava o reconhecimento de que diferentes sociedades se ocupam reflexivamente de diferentes dimensões do mundo. Isso não é um privilégio da ciência ocidental, isso não é um privilégio das escolas politécnicas, nada disso. Esse conhecimento também não se distribui de maneira, como é que se diz? Igual sobre todas as pessoas daquela sociedade. Existem especialistas, existem experts, existem naturalistas no sentido amplo do termo. Talvez seja o termo mais adequado pra falar desses saberes da botânica, da zoologia, da meteorologia. Então eu sempre fui fascinado por isso, sempre fui fascinado por isso e isso vai aparecer em vários outros trabalhos que eu também me dediquei junto com outros colegas, sempre. Eu fui então para Maricá fazer esse trabalho e a partir de uma coisa puramente, como o Felipe chamou atenção, uma intervenção para arranjar rede para pescador, fazer cooperativa de pesquisador, resolver problema de pescador, coisa que eu nunca 
consegui fazer, né, porque a ideia do programa era exatamente antes de você propor qualquer coisa dessas, conhecer os lugares para você poder ver as possibilidades da mudança social dirigida, porque era esse o objetivo, que os elementos pudessem ser digeridos por essas estruturas locais e de não digerirem as estruturas locais como normalmente acontece, né. Quando o acontecimento ele não pode ser digerido pela estrutura e ele é que digere a estrutura, então na realidade não era bem substituir o mundo do outro pelo meu, mas isso não era fácil porque demandava um tempo que não é o tempo da intervenção. Não é o tempo da política governamental, não é o tempo dessas formas através das quais o poder gosta de ser visto.

Então, passei quinze dias com o Henrique e isso foi muito importante pra mim, mas eu não ganhava dinheiro. Eu ganhava esse dinheirinho da Secretaria de Agricultura. Fiz um relatório, esse relatório existe e é citado nos trabalhos de folclore nesta região pela Cássia Frade. Ele ficou meio adormecido e, em 79, posteriormente tudo isso, em 79, o Arno Vogel me convidou para ir ao IBAM com ele porque eles estavam num projeto no Centro de Pesquisas Urbanas do IBAM e ele queria conversar comigo para saber o quê que eu como antropólogo era professor de Antropologia. Ele vinha de história, não é? Nunca tinha dado Antropologia. Não tinha feito pesquisa de campo. Ele perguntou se eu entendia de trabalho de sociologia urbana e eu disse pra ele que eu entendia de Antropologia, que esse negócio de Antropologia urbana, Antropologia isso, Antropologia aquilo, isso é um modo de declinar um conhecimento teórico, metodológico que se você não tem não adianta nada. Você não consegue operacionalizar isso em função do campo específico sobre o qual você vai se debruçar. Eu nunca tinha feito nenhum curso de Antropologia urbana, nunca fiz na minha vida.

Hélio Silva - Depois disso eu queria fazer uma pergunta...

Marco Antonio - Aí fui trabalhar, só pra concluir aquela parte, fui trabalhar então com Arno que coordenava uma pesquisa sobre a apropriação de espaços coletivos para fins de lazer, uma pesquisa financiada pela FINEP cujo projeto estava situado no Centro de Pesquisas Urbanas do IBAM, coordenado por Carlos Nelson Ferreira dos Santos. Arno coordenava essa pesquisa, o que também era muito estranho porque o IBAM estava acostumado com arquitetos trabalhando dentro do gabinete. Então, eu nunca trabalhei lá. Eu ia lá, mas trabalhava na rua. Então, às vezes, para administração superior do IBAM era difícil justificar porque as pessoas não estavam lá sentadas numa prancheta. 
Não só ficar sentado na prancheta, mas também porque arquitetos e urbanistas achavam que estávamos tirando o emprego deles. Consideravam que o objeto empírico (cidade, bairro, rua) era deles. E eu não sabia de nada disso. Só fui saber disso posteriormente pelas reações ao trabalho que realizamos. Então, eu fui me dedicar a isso e foi o primeiro livro que eu publiquei em 1980.

Terminei o trabalho, o livro foi publicado, teve várias edições e eu estava simultaneamente pensando nesse assunto Maricá, que eu continuei a frequentar por outros motivos, e com um problema que tinha a ver com cultos afro-brasileiros que se concretizou com a minha entrada para o Museu, que foi exatamente um trabalho que tinha, entre outras questões, um problema da Sociologia Econômica. O tema tinha sido formulado pelo Castro Faria. Tema, inclusive, que ele formulava para nós na graduação, que era uma afirmativa. Existe um universo de artigos religiosos, objetos, ponto. Estude os processos de produção, distribuição e consumo em função das práticas rituais a que se destinam. Eu fui estudar a iniciação, os custos da iniciação no candomblé, por vários motivos também. Eu nunca tinha me ocupado de cultos afro-brasileiros e nem de religiosidade afro-brasileira, apesar de ter convivido com isso desde criança. Mas nunca me ocupei, nunca frequentei e nunca tive nenhum tipo de manifestação que me aproximasse em nada dessa religiosidade afro-brasileira. Comecei a estudar o comércio, as lojas, ligados aos cultos. E percebi uma hierarquia na arrumação dos objetos. Exu está sempre embaixo e tal. Ao mesmo tempo, entrava freira pra comprar copo, comprar terço, velas, uma confusão danada.

Todo noviço tem uma lista dos produtos necessários para a iniciação. Com uma dessas listas fui levado para lojas Imperatriz, Das Sedas, açougues, supermercado, lugares inusitados Ou seja, muitos objetos viraram objetos do culto, entravam na cena ritual, Então, no meio disso tudo, aparecia em todas as listas que consultei depois a galinha d'Angola. Eu nunca tinha comido uma galinha d'Angola na minha vida e eu falei pô, galinha d' Angola. Eu trabalhava, eu já estava trabalhando no IFCS e tinha galinha d'Angola. Tinha dois aviários ali embaixo do IFCS, galinha d'Angola cantando o dia inteiro. Tinha um Peru em um dos aviários Sábado o dono abria e o Peru entrava pelo IFCS. Galinha d'Angola em tudo quanto é lugar e eu ia perguntar sobre a galinha d'Angola e a galinha d'Angola só se vendia inteira, não tinha quilo de galinha d'Angola, não tinha nada. Finalmente fui numa primeira cerimônia de candomblé. Era uma festa... 
não foi a primeira, foi a segunda, a primeira eu fui com os cenógrafos do filme do Nelson Pereira dos Santos que eram filhos de santo.

Fui ao candomblé lá no Jardim Catarina. Era uma saída de Iaô. Três saídas. Primeira saída do Iaô lá da camarinha, da câmara de reclusão, igual uma galinha d'Angola, todo pintadinho de branco, cabeça raspada, aquele troço oxu na cabeça. Falei para um cara que estava do meu lado, “mas aquilo ali é uma galinha d'Angola!" Ele respondeu: "mas é claro que é!". Então eu falei desculpa, eu nunca vi, não sabia e tal. Aí eu olhei e tinha um monte de pena de galinha d'Angola colado em cima de um... pezinho de galinha d'Angola, cabeça de galinha d'Angola. Tinha um fogão de lenha e vi que tinha umas mulheres com as peninhas da galinha d'Angola. Aí eu fiquei com aquele negócio na cabeça, galinha d'Angola e as pessoas falavam muito pouco. No açougue não se queria falar, no aviário, todo mundo... Coração, coração de boi sangrando, coração de boi sem ser sangrado. Eu comecei a ver que o circuito ia até dentro do matadouro. Você mata o boi, tira o coração, sangra o coração, depois você usa pra fazer comida em casa. Mas para o candomblé e para umbanda o coração tem que ser sem sangrar. Então tem tudo separado no açougue e tal. E as pessoas não necessariamente eram de candomblé, nem de umbanda. Eu estava na loja de fazenda o cara sabia o que era roupa de Oxum, como é que era aquele amarelo ou não, que era esse aqui. Um conhecimento impressionante da iconografia dos orixás. Fiquei com esse negócio da galinha d'Angola porque numa entrevista, neste momento, uma pessoa disse para mim que a galinha d'Angola, tinha todas as cores. Não pode ter todas as cores, mas tem todas as cores. E aí comecei a prestar atenção de porquê que você tinha, o noviço aparecia sobre uma espécie de galinha d'Angola e esse era o problema. Fiquei lendo, lendo Turner, até que propus para Arno. Falei com Arno uma vez sobre isso no Jardim botânico na Maria Angélica. Ele, um alemão do Vale do Itajaí, muito educadamente, não riu da minha observação, mas mais tarde se revelaria. Como uma coisa tão conspícua não ter sido observada e descrita por nenhum dos etnógrafos do candomblé? Nenhum! Roger Bastide, Carneiro, nem Pierre Verger. Nenhum deles descreveu ou mostrou essa relação entre a galinha d'Angola e o noviço. Isso me levou, me consumiu anos e eu acabei incorporando nessa conversa o Arno, meio incrédulo e depois o José Flávio Pessoa de Barros que aí sim a pesquisa, eu consegui convencer dois colegas, os quais eu respeitava e respeito muito, o Flávio morreu, e aos quais eu estava vinculado por relações profundas de amizade. 
Conheci Flávio descendo a escada do avião no Xingu. Ele já estudava os índios Ticão, estudava Antropologia física, biológica. Ele estudava dermatoglifo de índio, a palma da mão do índio, isso que ele estudava. Ele percebeu meu embaraço quando cheguei e vi aquele monte de índio. Eu fiquei parado fiquei alguns segundos parado olhando aquilo. Ele foi e disse: "vamos descer?", muito delicadamente. Foi junto comigo, mostrando para mim quem eram os índios. Ele já conhecia. Fiquei mais leve, digamos assim. Daí pra frente, eu ia visitá-lo. Eu saía da aldeia Awrá e andava alguns quilômetros na floresta para visitar Flávio entre os Ticão. Aí em 1982, 83, marcamos uma reunião no meu apartamento na rua José Bonifácio e Flávio veio com a primeira contribuição dele para nosso artigo que logo viraria projeto de livro, contra minha vontade porque inicialmente eu queria só fazer o artigo. Eu estava anos tentando terminar o artigo, mas cada um tinha suas obsessões. O Flávio com sua obsessão no Borí, no ritual que pra ele era terapêutico e eu disse, mas terapêutico em que sentido? Terapêutico? O que quê quer dizer isso? Eu tinha tendia pra uma dimensão da descrição, sair, evidenciar que dimensão terapêutica era essa, que isso era um rótulo que você botava, mais um rótulo que você botava numa coisa. E aí a contribuição dele foi uma ficha. Biólogo que ele era, advogado e antropólogo que tinha feito doutorado na USP sobre etnobotânica das casas de candomblé, muito posteriormente a essa conversa do Xingu. Ele trouxe a classificação da galinha d'Angola. Voltando ao negócio do conhecimento, a classificação científica da galinha d' Angola de Lineu. Então estava lá a ficha, "aqui está minha primeira contribuição". Então, na galinha d'Angola estava Numida meleagris. Aí eu olhei e falei o que isso sugere a você, Flávio? O Flávio ficou embaraçado: "Isso aqui uma letra minúscula disso e tal, isso é uma classificação". Eu disse: eu sei, mas o quê que é esse nome aqui? Aí Arno falou "numida é da Namíbia, norte da África, pega isso tudo e meleagris. Ah não! Meleagris tem a ver com Meleagro. Eu me lembrei do livro de Câmara Cascudo de meleagris. E aí fui procurar o negócio da história de Meleagro para chegar as meleagris para ver como a galinha d'Angola tinha essa vocação simbólica, como chama atenção Turner, então essa vocação simbólica em diferentes culturas, ela expressar diferentes tipos de pauta daquela cultura. No caso grego, luto, o pranto pelo ente querido. A história de Meleagro, um dos argonautas, né. Meleagro é um dos argonautas e que o vídeo das metamorfoses vai dedicar uma parte linda que é sobre a caça no bosque de Calidon que é exatamente o momento em que Eneu, que é o pai de Meleagro, Altéia é a mãe de Meleagro. Eneu pede aos argonautas, porque ele 
tinha feito os sacrifícios, as primícias, mas tinha se esquecido de Artêmis e Artêmis fez se abater sobre o reino de Eneu um infortúnio sob a espécie de um imenso, monstruoso javali que estava destruindo tudo. Então, os argonautas vão à caça ao javali e aí quando Meleagro vê o javali e ele vai jogar sua lança, ele olha pro lado e vê uma moçoila que é um misto de moça com efebo, trigueira, aquela coisa queimada do sol com um saiote, um cabelo preso, maljava e ela flecha primeiro do que ele o javali. Ele fica apaixonado por ela, como os franceses falam, como se fosse um raio que se abateu sobre os dois, só que o javali não morre. Então ele vai, joga sua lança finalmente abate o javali, pisa sobre ele, corta a cabeça do javali e dá o troféu, a peça venatória pra ela que é Atalanta, pomos de ouro. Os tios maternos estão caçando com ele dizem: "Alto lá! Nós somos seus tios maternos e nós temos precedência sobre qualquer um que está aqui na distribuição dessa peça venatória e ela além do mais é mulher". Aí com aquela híbris toda, aquela arrogância toda que caracteriza os heróis gregos, essa desmedida. Ele vai, desafia os tios, luta com os tios e mata os dois tios tal como os ideais gregos da Aristeia, do combate simular, da arete da demonstração dessa virtude e da reafirmação do seu caráter de melhor, de arestoi. Só que Altéia, mãe dele, não sabe se rejubila com essa demonstração toda de seu filho ou se fica profundamente triste porque o direito criminal e o direito de família obrigam-na a vingar seus mortos. Abre uma caixinha e dentro dessa caixinha tem um tição que ardia na lareira doméstica na estia quando Meleagro nasceu... Vieram e disseram para ela: "a vida do seu filho vai durar enquanto esse tição durar". Ela vai, tira o tição da lareira, da estia e guarda com ela. Nesse momento, muito entristecida, abre a caixinha, pega o tição e lança o tição outra vez na lareira e o tição se consume. As irmãs de Meleagro, que adoravam o irmão, depois chorando, gritando, se jogando em cima das cinzas do irmão, passando as cinzas sobre o corpo, gritando, gritando, gritando. Artêmis fica tão aporrinhada com aquele pranto, aquele plancton como os latinos chamavam que está na epigrafia toda do pranto ritual. Ela vai, não aguenta mais e as transforma em meleagris, em galinhas d'Angola, em pantadi, em Guiné, que cobrem o seu corpo com as lágrimas, o seu luto e choram até hoje a morte do seu irmão. Então, a galinha d'Angola era nos tempos de Ártemis uma vítima sacrificial preferencial. Bom, isso no mito grego.

Depois o quê que nós fizemos? Nós fizemos aquilo que a gente aprendeu com LéviStrauss também. Nós mergulhamos na galinha d'Angola. Começamos a ler sobre uma descrição da galinha d'Angola, o bicho, então Aristóteles que descreveu a galinha 
d'Angola, Plínio e fomos descrevendo. Pegamos pra trás porque do século, só no século XIX, na segunda metade do século XIX, eu acho que um naturalista descreveu esses animais no campo, in situ. O resto tudo escrevia no laboratório, porque toda essa zoologia é feita com cadáveres. Essa etiologia é feita em laboratório com cadáveres. Esse ectiólogo pra ele é irrelevante o comportamento do peixe. Ás vezes são mudanças discretas ao longo da vida, como mudanças discretas no comportamento dos pássaros, mudanças discretas no comportamento das aves. Então, o século XVII é fantástico porque vai rompendo com essas categorias e essa lógica das qualidades sensíveis, mudando tudo. Então, você vê isso nos tratados de zoologia. Mas isso não resolvia problemas, por exemplo, como é que a galinha d'Angola tem todas as cores? Aí você tem sempre a possibilidade da interlocução. Eu tive esse privilégio. Eu já disse que tive o privilégio de ter bons professores na graduação e tive o privilégio de ter bons colegas no programa de pós-graduação no Museu Nacional, com os quais eu pude estudar durante todo, ler tudo que eu gostaria de ler discutindo com os colegas, não coisas que eu não soubesse que existisse, mas realmente ler, estudar sistematicamente, por um período muito mais longo do que o período que uma disciplina na graduação ou duas disciplinas na graduação permitiriam a você. Encontrei entre esses muitos colegas um que reunia todos esses qualificativos, sobretudo, uma imensa curiosidade e uma disponibilidade para essa viagem, que foi o Arno. Então, nós líamos, líamos e tal. E tivemos a cumplicidade de dona Margareth da Cosmos que deixava a gente fazer cópia de livros que de outro modo seriam inacessíveis aos nossos bolsos, por exemplo, as edições Bufon que descrevem. Então, realmente se foi fazendo isso de uma maneira... e todo mundo sabia que nós estávamos estudando a galinha d'Angola, o porteiro do prédio, as secretárias do instituto, todo mundo sabia. Isso é importante, quando você está fazendo pesquisa de campo isso tem que ser um assunto seu.

Hélio Silva - Eu faço isso em todo meu trabalho de campo. Eu falo, só falo naquele assunto pra todo mundo. Isso eu faço mesmo, engraçado.

Marco Antonio - E aparecem coisas fantásticas!

Hélio Silva - A gente termina chato, né, mas foda-se.

Marco Antonio - Mas não, depende do jeito que você conversa, como você conversa.

Hélio Silva - Mas as pessoas que estão circulando... 
Marco Antonio - Você achou chata essa história do Meleagro?

Hélio Silva - Não! Eu estou dizendo o seguinte...

Marco Antonio - Não é, né?

Hélio Silva - Não, claro. Mas para as pessoas que estão mais intimamente, quer dizer, essa obsessão termina...

Marco Antonio - Ah!

Hélio Silva - Eu estou me lixando na hora que eu estou trabalhando...

Marco Antonio - As pessoas não querem ouvir mais nada, né? Não precisa ser Walter Benjamim para descobrir isso. A gente descobre a toda a hora, né? Ninguém quer ouvir mais nada. Ninguém sabe ouvir mais nada e também não sabe contar.

Hélio Silva - Ainda tenho duas... você tem mais alguma questão pra fazer pra ele?

Marco Antonio - Peraí, só um instantinho, deixa eu acabar...

Hélio Silva - Tá bom.

Marco Antonio - Tive ainda o privilégio de ter compartilhado no IFCS de uma convivência que vejo hoje como singular nas universidades brasileiras. Não é só brasileira não, porque os departamentos acadêmicos são a menor unidade administrativa da universidade e a menor unidade em termo de qualquer discussão intelectual. Não existe isso nos departamentos acadêmicos brasileiros, não existe. Ah! Não existe? Não existe. Não existe por uma razão muito simples, se você for discutir coisas acadêmicas no departamento, o departamento é capaz de se dividir todo e todo mundo brigar porque ninguém sabe exatamente fazer esse tipo de diálogo ou de se maravilhar diante do colega e da descoberta do colega e trazer, botar sobre a mesa também suas histórias. Então a possibilidade de você gerar clivagens, gerar mal-estar é muito maior. Então, eu entendo porque as pessoas não querem. Por exemplo, fazem uma viagem. Na reunião do departamento ninguém fala sobre o que aconteceu. E se você quer falar, "não, não, não precisa falar" porque se falar, você introduziria uma regra, mais ou menos uma regra ou um hábito de todo mundo poder trazer a sua... Mas eu tive esse privilégio, não por causa de um departamento, mas por causa de muitos departamentos que conviviam no IFCS 
num botequim, num bar no terceiro andar Então, ali eu pude conviver com Mário Guerreiro, que era professor de estética, com José Américo da Mota Peçanha, com Manuel Carneiro Leão, com Michel Misse, sociólogo que era meu colega, mas era ali a conversa, com Aluísio Alves que era interessado em Monteiro Lobato e pensamento social brasileiro e muitos outros colegas, Olinto Pegoraro. Cada um deles, eles podem nem ter ideia, eu procurei sempre mencionar o quanto devo a essas pessoas, a essas conversas ali. Inclusive, recolocar o Luckács, mas isso é [...] Então, por exemplo, a teoria das cores que o Turner está usando, embora não fale disso, é substancialista, uma teoria africana. Essa teoria é a teoria de Geertz que se contrapõe, não a teoria de Newton das cores que está no primeiro capítulo da Ótica, mas ele está dizendo o seguinte: olha, existem outras teorias. Os defensores dessa teoria se preocuparam tanto em defender essa teoria criaram tantas torres para defender a teoria que se esqueceram pra saber se essa cidade é habitada. Não estou dizendo que a teoria do Geertz é melhor que a teoria do Newton em física, absolutamente. Mas a teoria do Geertz oferecia uma possibilidade de compreender esse enunciado "a galinha d'Angola tem todas as cores" e compreender melhor ainda que a pintura corporal, no caso do candomblé, porque eu não vi isso na etnologia indígena. Porque a pintura corporal no candomblé não é uma pintura, ela é também a imposição de substâncias no corpo do noviço. A pintura em grego, a palavra para remédio é a mesma palavra para cor. Então na realidade, quer dizer, aquela mão de Egun que fala no candomblé é só uma mão que não vai pintar nada, pintar um índio que vai sair no Cacique de Ramos. Ela está infundindo substâncias. Então esse mundo é um mundo interessante também desse ponto de vista de você pensar por que que ela representava tudo isso? Porque estava no horizonte do Iaô em termos de realização plena da vida. Por isso que eu disse a você, Hélio, falar sobre etnografia, descontextualizada dos trabalhos que você realiza, é difícil porque eu perdi um tempo enorme. $\mathrm{Eu}$ acho que eu perdi um tempo enorme falando com você sobre coisas descontextualizadas do que eu fiz. Eu tinha pensado exatamente em fazer o contrário. Então, como o Perec chama atenção lá no trabalhinho dele que eu trouxe exatamente para mostrar [...].

Hélio Silva - Bem, eu queria perguntar uma coisa a propósito disso, só lhe interrompendo. Eu falei que a entrevista se estruturaria num fluxo... mas não quero ser extremamente rigoroso com isso. Eu quero perguntar uma coisa para você. Ao mesmo tempo que você diz, e eu entendo, que eu não posso falar de etnografia... 
Marco Antonio - Mostrar como eu fui fazendo.

Hélio Silva - Por outro lado, você além de desempenhar o papel de etnógrafo, você desempenha um outro papel, o papel de orientador, quer dizer, nesse papel essa relação... Eu vou fazer as perguntas que eu tenho juntas e depois você responde. Quer dizer, como é que se orienta uma etnografia? Outra coisa que eu queria te perguntar é o seguinte, existe uma história dos métodos etnográficos? Todo mundo fala de uma história da Antropologia. Existe uma história que está associada a outra pra quem, particularmente, tudo é Antropologia urbana, embora eu entenda o que você está dizendo sobre especialização em áreas empíricas assim e não a partir de questões. Quer dizer, falar em escola de Chicago é falar de um colarinho muito folgado no pescoço de qualquer um porque são tantas as experiências, mas de qualquer maneira a escola de Chicago que me interessa. Quer dizer, ela foi... está associada a essa história do método, ela ainda... o fenômeno urbano hoje é ainda alcançável por esta escola? Enfim, avalia essa escola porque você trabalha muito com essa gente e você conhece muito disso.

Marco Antonio - Porque o seguinte, Hélio...

Hélio Silva - Há uma história do método etnográfico?

Marco Antonio - Eu acho que não. Eu acho que na realidade quando você... por exemplo, Marcel Griaule vai escrever um trabalho, ele escreve um livro sobre método etnográfico e ele, por exemplo, ele era um homem completamente alucinado, uma pessoa importante, o grande, o diretor da primeira e grande pesquisa etnográfica francesa, para quem Mauss vai inclusive escrever, aluno de Mauss, mas um piloto completamente alucinado. Ele vai fazer uso de fotografias aéreas, fotografia aérea vertical, depois o Bordeleau vai fazer isso. Isso vai aparecendo em todos os manuais de etnografia francesa. São manuais tardios no sentido de recomendações e tal, esses manuais. Embora, no... na Inglaterra, mas muito antes disso você tem lá em 1800 na virada 1799 e 1800, As Sociedades Observadoras do Homem.

Marco Antonio - Você tem vários trabalhos, vários livros de métodos, vários "hands books" que no fundo você tem sempre o problema de no máximo funcionar como uma espécie de lista de mémoire. Você vai para o mercado você tem que ter uma lista para 
você saber o que vai comprar e te orientar mais ou menos ali. Isso Malinowski também está falando, Evans Pritchard está dizendo isso também naquelas Reminiscências sobre o trabalho de campo que ele escreve. As técnicas de você usar não são do etnógrafo. $\mathrm{O}$ argumento contrafactual você usa em qualquer lugar, tá entendendo? Você usa frequentemente no tribunal, você usa em tudo quanto é lugar, não é? E o Griaule usou isso, ele dizia que o etnógrafo deve se comportar como... [alguém que] realmente ele encarna tudo aquilo que o etnógrafo profissional encarna, quer dizer, como é que ele pega as informações, como separa as informações porque o mundo social, como em qualquer lugar, é o lugar da controvérsia, como eu já disse. É uma confusão dos diabos, né. Então e ele cometia excessos, né? Estava dando uma entrevista para você aqui e ele levava o cara para outra aldeia para o cara ficar apavorado que ele estava falando do mesmo assunto numa outra aldeia pra um outro grupo. Então, ele criava essas situações embaraçosas e ele escreveu alguns trabalhos muito importantes para Antropologia, mas sempre desqualificados pelos franceses. Os franceses sempre querem arranjar um cara mais distante e melhor, melhor, mais bonito e tal e você só esculhamba o Griaule.

Marco Antonio - É engraçado porque ele foi entronizado no pantheon Dogon. O ritual mortuário de Griaule é uma coisa fantástica e foi filmado inclusive. O seu companheiro de pesquisa, como é o nome dele?

\section{Helio Silva - Jean Rouch?}

Marco Antonio - Jean Rouch. Os problemas todos de documentação, a câmera de cima pra baixo, de baixo pra cima, aquilo... As montanhas nas falésias de Bandiagara, um troço complexo, cujo plano da aldeia, do ponto de vista urbanístico, arquitetural, é uma coisa fantástica e não tem nada a ver com funcionalidade. Está longe da água, longe dos patos, completamente distante. Um troço incrível. Têm aquelas casas todas associadas a coisas sexuais. Aquela escada que parece uma vagina, outra que parece um pênis. Enfim, uma loucura total. Aí as acusações de que ele roubou, roubou peça, levou pra não sei aonde. Tem sempre uma história dessa.

Para voltar à Antropologia urbana, a família de Doc dizendo que Foote Whyte roubou, que na realidade ele que era a coisa. O que eu quero dizer é o seguinte: o antropólogo deve a sua história àquelas pessoas com as quais ele trabalhou, e nós contamos a nossa história. Nós ouvimos um monte de história e nós contamos a nossa história. A história 
que nós aprendemos ouvindo as histórias dos nossos anfitriões, devolvemos pra eles. É preciso estar atento a isso que você não está fora desse mundo. E se você está falando de anfitrião, porque o antropólogo precisa de um anfitrião, ele é sempre um hóspede, você tem que falar das regras da hospitalidade. Entre as regras da hospitalidade, pelo menos na sociedade mediterrânea, que eu acho que vale pra muitas outras, está a ideia de que você é brindado com comida, música, dança e tal, história, e você também deve contar as suas histórias. As pessoas também querem ouvir você, e as histórias que você conta sobre eles mesmos. Então pra voltar ao assunto lá de Felipe, quando eu botei na casa que eu morava com Denise Maria Duque Estrada em Zacarias, era um monte de papel colado. As pessoas passavam e tiravam o chapéu, tiravam o chapéu. Não é metáfora, conversa fiada da Califórnia. Tiravam o chapéu, se emocionavam com aquilo que eles compreendiam o que era aquilo.

Um disse "Essa foi a coisa mais importante que o senhor já fez por nós, professor", e chamava os filhos e os netos pra ver onde é que eles estavam na genealogia. Então a genealogia é que os ancorava no mundo e dava fundamentação, verossimilhança às suas narrativas, que eram contrapostas à história. A história que, de acordo com Ranke, a Cátedra de História de Berlim desqualificou todas as outras formas de fundamentação de direitos. Entre elas as sagas, as narrativas. O negócio é o documento. Então eu sempre desconfiei de historiador que faz história oral, porque eles querem mesmo é um documento. E eu disse isso pro Richard Price. Por que ele foi buscar documento nos arquivos na Holanda, em Amsterdam? Ele entendeu a pergunta. Os historiadores que estavam ali acho que ficaram revoltados, mas ele entendeu. Eu falei "porque eu não fui buscar documento nenhum em nenhum arquivo paroquial". Ou seja, as suas narrativas têm consistência interna e coerência no mundo envolvente ou não tem? Elas são ou não são um documento pra você? Ou elas precisam do artifício positivista da historiografia do início do século XIX, que vai fundar essa moderna historiografia? Que vai desqualificar historie em detrimento da Geschichte, que já contém uma outra teoria da história. Historie tem uma teoria da história, a narrativa, e Geschichte tem outra, que é aquilo que está estabelecido, e que já contém uma teoria estratigráfica dos acontecimentos Geschichte. Então o trabalho etnográfico ele também ensina você, voltando lá ao Malinowski. Você aprende no trabalho de campo, você também vai adquirindo isso, você vai fazendo isso ali também. Esse negócio que nós estávamos falando do Griaule, dos métodos, quer dizer, você tem várias maneiras, há técnicas 
muito sofisticadas hoje. O computador coloca uma porção de possibilidades pra você trabalhar com genealogias, há muitas possibilidades. Dependendo do assunto.... Por exemplo, quando eu fui estudar Zacarias, tinha coisas que nenhum antropólogo podia responder para mim, só um botânico e outros especialistas de outras áreas. Alguém para explicar o que era uma laguna. Nenhum antropólogo nunca me explicou. Eu acho que não tem nenhum livro de Antropologia que diga o que é uma laguna como eu digo no meu com Arno.

Hélio Silva - E não só isso. Ele é crivado de detalhes preciosos.

Marco Antonio - Agora eu queria entender o enunciado nativo, porque esse que é o problema. Nós fizemos os cursos do Museu Nacional num momento exatamente dessa virada do estruturalismo, do marxismo, essa crise. Nós entramos por uma discussão da filosofia analista da linguagem de um modo excepcional naquela época. Pelo menos eu, Arno, Eduardo Viveiros de Castro, porque nós fazíamos curso juntos, o Anthony Seeger. Fizemos um seminário sobre semântica, sobre essas coisas. A metáfora, a teoria da metáfora. Isso era muito importante porque isso fazia sentido com as coisas que eu conversava com os meus colegas de Filosofia, e fazia sentido com meus colegas de História, que tinham estudado na Alemanha. Hoje não tem nenhum que fale alemão, que dê aula de metodologia da história, nem na UFF e nem na UFRJ. Era complicado porque isso tornava possível uma colaboração não estruturada por nenhum projeto anterior, mas com uma grande generosidade, uma capacidade de interlocução que tornou possível essa conversa. Seguindo a lição de Marcel Mauss, de Lévi-Strauss, e tal. Quer dizer, eu tinha lido com Arno aquele trabalho sobre a L'école Chic, que é um poema de Apollinaire. Esse poema de Apollinaire tem uma frase incompreensível que gerou artigos, livros, chama-se mères filles de leurs filles. Um poema de Apollinaire, que se chamava Apolinários, que foi um cara fundamental para a Antropologia francesa, para arte, para tudo. O que Lévi-Strauss vai fazer? Ele vai mergulhar na planta e vai elucidar a partir da planta porque que mères filles de leurs filles faz sentido. Porque a flor aparece primeiro que... $\mathrm{O}$ fruto aparece primeiro que a flor, a flor aparece primeiro. Então é uma inversão total porque é ele um rizoma. Então o mutatis mutandis é mergulhar no objeto, o bicho, estudar a galinha da angola, estudar a laguna. Porque o pescador dizia para mim, outro enunciado nativo: "A lagoa é a lavoura do pescador". Em que sentido? É uma metáfora? A lagoa está para o pescador assim como a terra está 
para o agricultor e acabou o assunto? Isso aí é de uma pobreza.... Não diria uma pobreza, mas de uma precipitação etnográfica nas evidências primeiras terrível. Eu resolvi tomar isso literalmente, eu tinha que responder isso literalmente. Se eu não conseguisse responder isso literalmente, provavelmente eu não tivesse compreendido aquele tal ritual que eu tinha visto com o Kant logo no início da história quando nós fomos lá ver a mortandade de peixes. Porquê de fato tratava-se de um grande rito, um rito de semeadura da lavoura do pescador. Mas eu só podia compreender que isso era uma lavoura quando se revelasse cinco anos depois de pesquisa de campo, o informante, Miolo, hilário, disse "Senhor Mello, o senhor está aqui há muitos anos interessado nesse negócio de pesca de galho, né? Pesca de lugar... Mas o senhor ainda não entendeu, né? " Ele não falou "não entendeu", ele foi muito delicado, não falou "não entendeu", ele falou, "mas o senhor não compreendeu bem”, aí eu falei "não", "então eu vou explicar para o senhor". Aí me convidou pra dar um mergulho imaginário na lagoa, e começou a dizer pra mim... Eu sabia o que era o galho. O cara cortava o galho, vinha com a canoa sozinho, depois de muito tempo. Aliás, cortava o galho na restinga, botava o galho na beira da praia, da lagoa. O galho secava, depois de algum tempo do galho seco ele botava o galho dentro da água, amarrava o galho pro galho ficar encharcado. Depois então um dia ele tomava uma decisão de pegar esse galho e levar esse galho amarrado ao longo da laguna, até chegar a um lugar onde ele fazia triangulação, sem GPS, fazia a triangulação, largava o galho, e esse galho repousava no fundo da laguna que era lama, é lama. Eu achava, que influenciado pelo Castro Faria, que tinha estudado a pesca na Lagoa Feia, que um pesqueiro era apenas um ponto geodésico que você marcava lá, então você voltava lá. Você encontrou o peixe ali, você encontrou o peixe num lugar, como você tem no mar, que o Cordel estudou, esse pessoal todo que estudou nordeste, Arembepe, a puta que pariu todo mundo estudou. Eles falam de um pesqueiro, a marca, o direito à marca, da propriedade. Existe uma pedra. Então eu vou lá, encontro aquela pedra, então aquela pedra, tem um monte de peixe ali, eu marco aquele lugar e volto lá. Não digo pra ninguém que tem aquilo lá. Todo mundo tem um conhecimento naturalístico como eu tenho capaz de encontrar um pesqueiro. É sorte e azar. O Castro estava muito voltado pra isso, a marca, o lugar. Só que o lugar não era nada disso. Lugar era um artefato. Ele era uma coisa, ele era produto do artifício humano. Era uma construção, não era uma pedra que estava no fundo da lagoa. Então eu achava que era isso. Bom, criou lá um nicho ecológico. Botou lá o troço, marcou, vai lá e encontra 
peixe... E esse Miolo, hilário, ele me diz o que acontecia com o galho. O galho fica lá, depois você vai, puxa o galho um mês depois pelo pé do galho com um gancho enorme de madeira. Aí vê se o galho está com musgo, com baba de velho, então... A rigidez da água tá boa. Semanas depois você vai lá e olha o galho outra vez, levanta o galho até a superfície e vê se ele tem craca, um balanídeo, um balano, um balanomorfus, vê lá, são indicadores biológicos. Aí vem o peixe, isso é que eu não sabia, vem o peixe. A tainha vem, fica encantada com o chiado, aquelas bolhazinhas que a craca faz no galho, ela fica encantada. Ela fica ali olhando, encantada com aquilo, mas não come. Aí vem o bagre. O bagre vem, olha aquilo ali, a craca vem, bota a linguinha pra fora, ele 'plac', come. Aí ele come a outra, aí vem o outro... Aí desce do galho, chega no pé do galho tem um monte de sarnambi no fundo, ali em volta do galho na lama. Ele vai tirando a lama, vai tirando a lama, vai fazendo uma buracaria, vai tirando a lama, vai tirando a lama, vai enfiando aquilo ali e aí vai comendo. Aí é fácil, vai ficando por ali. Quem é que não quer comida fácil? Fica na sala, vai pra varanda, fica na cozinha do Felipe, fica ali e tal, não sei quê. [Risos]

Aí que eu entendi o que era o lugar. O lugar é feito pelos peixes. O galho é o epicentro de um lugar, que é um lugar que a lama saiu toda. Os peixes fizeram aquilo. Aí ele disse pra mim: "Eu botei mais de cem galhos nessa lagoa. Ari quantos não terá colocado?" Tinha o Henrique, que é o mais velho. Quantos não terá colocado? Aí eu vi, pela primeira vez, a laguna arroteada, crivada de galhos, e aí eu entendi o que era o labor, esse labor, essa lavoura do pescador. Eu entendi que era um artifício. Então um artifício humano construído em consórcio com o peixe, então os dois, é uma coisa incrível que faziam. Aí eu entendi porque que tinha aquela abertura da barra era tão fundamental, porque era ela o Le rite de semaille, o rito de semeadura dessa lavoura do pescador. Eu demorei anos pra entender isso. Aí eu vi que eu devia ter tomado literalmente, e portanto, a expressividade da abertura da barra, que é o único caso no mundo de tudo que eu li, onde se tem um cântico, onde você tem um ritmo. Não é arbeiten rhythmus não, como dizia lá o professor do Malinowski, de Boas, de todo mundo, que era um evolucionista. Mas realmente e era uma adivinha portuguesa o tangolomango, que é uma espécie de Trickster Mlangeni e pode inverter aquilo e fazer uma confusão danada. "O tangomangolango matou sua mulher / Botou no cesto e mandou vender / O povo dizia que era" [cantando]. 
Hélio Silva - É uma expressão que povoou a minha infância... na sua também?

Marco Antonio - Esse incremento da vida, isso que Rocard, o Mauss belga, vai falar desse incremento da vida que na realidade é uma celebração do incremento da vida. É um incremento da vida que você deve ver, então você leva as crianças pra ver, pra ensinar elas a ver os alevinos entrando, essa coisa fantástica. Eu disse "pô"... Eu demorei um tempo pra fazer isso. Então essa sofisticação desse conhecimento naturalístico... O cheiro do peixe, o peixe tem cheiro. Você se localiza pelo cheiro do peixe pescando. O robalo, sai uma oleosidade dele, das glândulas dele, que sobe à superfície, e o pescador, que está acostumado com aquilo, sente aquele cheiro. Vai e vê qual é a direção do vento. Então ele começa a encontrar pelo vento, e quando some o cheiro é ali que está o robalo, por ali. Então o cheiro do peixe, o brilho do peixe.... Nenhum pescador jamais disse que parati é uma tainha pequenininha como uma tainhota. Todo pescador, em qualquer lugar do Brasil, dirá pra você que o parati não é uma tainhota. E como que ele faz isso? Ele mostra pra você. Ele vai vindo de barco e diz "Olha, tá vendo ali um cardume? Presta atenção, aquilo ali é parati." Ele joga a pedra, 'pá', o peixe faz assim e desaparece. “Agora aquilo lá é tainhota. Tá vendo ali? Presta atenção", joga a pedra e o peixe faz assim, ela vem. Isso é fundamental se você quer pescar.

Hélio Silva - Quando é que sai Gente das Areias, a segunda edição?

Marco Antonio - Deve sair por agora.

Hélio Silva - É? Sai por que editora?

Marco Antonio - Pela EdUFF.

Hélio Silva - Pela EdUFF, ah tá.

Marco Antonio - E vai sair a quarta edição de Quando a rua vira casa pela EdUFF também, porque o Vicente Wissenbach que foi o editor da terceira edição da editora Projeto, nós fizemos contato com ele. Ele veio todo feliz porque ele todo o material de Quando a rua vira casa, então é facílimo pra fazer a nova edição. Eu estou fazendo uma introdução grande com o Arno, fazendo esse balanço todo.

Hélio Silva - Aquele material com aquele rapaz que.... Como é o nome dele? 
Marco Antonio - Molica.

Hélio Silva - Molica.

Marco Antonio - Tá tudo lá direitinho ainda.

Hélio Silva - Molica é vivo ainda?

Marco Antonio - Não, morreu.

Hélio Silva - Eu conheci ele na Santa Úrsula.

Marco Antonio - Morreu Molica...

Hélio Silva - Ele fazia alguma coisa lá na...

Marco Antonio - Ele foi professor, ele foi professor lá. Ele fez dissertação de mestrado na ECO sobre isso, mas muitos anos depois, eu não sabia. Quem me deu inclusive o trabalho dele, uma cópia, foi a Karina Kuschnir, porque ele foi professor dela na Santa Úrsula.

Hélio Silva - Mello, eu estou prenhe de ideias e satisfeito. Agora não sei se você quer dizer alguma coisa que a gente não tenha perguntado...

Marco Antonio - Não, você perguntou ainda um negócio sobre o método, né? Quer dizer, eu não vou dizer essas obviedades que método, como dizia aquela... que o Georges Dumezil reproduz em Mitra-Varuna, quando ele diz que Marcel Granet no laboratório quando ele entrava ele dizia: La méthode, c'est le chemin, après qu'on l'a parcouru, ele fazia essa brincadeira, e que é difícil explicar isso pra um estudante. Porque nós temos uma teoria também maluca, pedagógica, que você tem que começar com as coisas simples e ir pras coisas complexas. Isso não funciona quando você vai fazer alfabetização bilíngue. Por exemplo, o professor Melià, Bartolomeu Melià, houve uma época que nego queria alfabetizar os índios do Xingu. Aí trouxeram ele pro Museu que era um negócio meio absurdo. Não, fazer alfabetização é ótimo, mas ele estava dizendo o seguinte: que a palavra água, "eau”, formalmente ela é muito simples de você escrever, bota um "y" aqui, "eau”. Só que para os guarani, ninguém começa a tomar contato com "eau" como se estivesse tomando contato com o método da abelhinha, que é um método de alfabetização. Porque a criança quando ela toma contato com essa ideia 
de água, "eau", vem junto com o mito, uma coisa danada. Eu acho que é difícil, realmente é difícil escrever. Falta eu dizer uma coisa, duas coisas importantes. Requer muita maturidade, eu reconheço. A forma canônica da dissertação é muito mais simples. Uma introdução, que já é o primeiro capítulo, fora os agradecimentos, que jamais agradeça a Deus, que eu não deixo de jeito nenhum, rasgo tudo, comigo não! Não tem nada de Deus, graças a Deus, vai lá pra... e bota lá a tese pendurada, mas comigo não, eu não aceito, eu interfiro nos agradecimentos, coisa que os meus colegas que dizem que eles não interferem, que é a única coisa que eles não... Eu interfiro porque os agradecimentos se revelaram pra mim sendo uma das coisas mais difíceis de serem feitas numa dissertação ou numa tese. Mais difíceis! As pessoas choram, choram! O ressentimento aparece, a inveja, a disputa e o não apaziguamento que você tem que ter quando você termina um trabalho, uma dissertação, uma tese, mas não um agradecimento assim genérico, um agradecimento mesmo, ao que se deve, o que tem, o que não tem, e tirando o mais positivo que você puder tirar de todos esses encontros. Então é muito difícil você ter essa coisa mais elaborada do ponto de vista da escrita. Inclusive porque nem todo mundo tem esse talento, nem todo mundo tem essa atitude diante do conhecimento e da Antropologia. O cara pode estar ali porque ele quer ter um título de mestre pra fazer qualquer outra coisa, ser funcionário da FUNAI, bater carimbo não sei onde, qualquer coisa. Então nem todo doutor em Antropologia é meu colega, nem todo mestre em Antropologia é meu colega. Há uma diferença muito grande entre você reconhecer um colega e uma pessoa que tem um título. Isso aí é outro assunto. Coisa que eu também custei a entender. Eu confundia o título com o conhecimento. Isso não tem nada a ver. O título é um título e acabou. Eu conheço várias pessoas que são mestres em História e que são joalheiros, um por exemplo. Conheço outros que fizeram Antropologia por prazer, por... Como é o nome quando você diz que uma pessoa é... Tem o profissional e tem o...

Felipe Veiga - Diletantismo.

Marco Antonio - O diletantismo...

Hélio Silva - E pra conviver com pessoas interessantes, não é Mello?

[Risos] 
Marco Antonio - Pois é... pois é, o cara quer fazer Antropologia pra ficar frequentando, pra dizer e tal, ter um bom assunto. Chegar no Centro Cultural do Banco do Brasil e ter uma pauta de conversa e depois comer um...

Felipe Veiga - Festas, né?

Marco Antonio - Festas, é. Então quer dizer e isto você saca longe, saca longe. Eu digo isso do filme, a atitude de Edward em Belleville em relação a mim, porque tem sempre um antropólogo, tem sempre um sociólogo, tem sempre um estudante pra perguntar uma coisa, mais um. Então como eu digo lá na conversa sobre o Eduardo, tem gente que é especializado em farejar esse falso intelectual, esse falso antropólogo, falso etnógrafo, falso tudo. Não tem estofo, como a gente diz, ele está lá e isso você reconhece longe. Eu vou terminar com a seguinte história: eu fui co-orientador e fui da banca de tese de doutorado na École de um colega nosso, que hoje é professor em Paris Dez. Ele tinha uma namorada, e essa namorada e ele sabiam que eu tinha lido o livro de Georges Condominas, L'Exotique est quotidien, e tinha lido outro livro dele magnífico, mais famoso, sobre, Nous avons mangé la forêt, e está traduzido em inglês inclusive em... Harvard os alunos são obrigados a ler essa grande etnografia dele. E um dia ele e ela, talvez pra se livrar de mim um pouco também sair pra fazer outra coisa: "Eu vou na casa de Condo". Condo era Georges Condominas que tinha praticamente criado ela, e o companheiro da mãe dela eu tinha conhecido porque era o cara que tinha vindo fotografar a inauguração de Brasília, e tinha sido o cara que acompanhou Condominas pra fotografar 50 anos depois o trabalho de campo de Condominas, tal. Aí ela falou "Mas nós vamos ficar só um pouquinho lá, uns cinco minutos. Ele tá meio cansado, tá doente, tá trabalhando". Depois eu fui saber porque, porque ele estava tão ansioso. Aí fomos pra Tolbiac, chegamos lá, fui pra casa dele. Cheguei lá, ele nos recebeu assim, um senhor alto, com aquela cara de chinês, asiático. Sentamos pra conversar. O que ia ser cinco minutos, durou a manhã e a tarde toda e foi em torno de etnografia. Ele foi ficando excitado e dizia pra mim "Poxa, mas a gente gosta mesmo disso". Começamos a falar de questões etnográficas. Depois descobri que ele podia ler português, que ele tinha comprado Pierre Verger pra estudar cultos vodu na África, que a avó dele, tal como o meu bisavô, a avó dele era portuguesa, asiática e o meu bisavô era chinês, então foi uma coisa muito engraçada. Então eu disse pra ele 'Pois é, eu li L'Exotique est quotidien, mas sobretudo um capítulo, mas parei num capítulo que eu nunca li todo 
porque eu tinha medo de me decepcionar". Ele olhou pra mim e disse chama-se "de la nécessité d' ethnographier l'ethnographe", a necessidade de etnografar o etnógrafo. Eu achei esse título tão... Eu falei isso pra ele. Eu achei o título tão forte, tão impressionante que eu não quis ler o capítulo porque eu tinha medo de me decepcionar. Ele ficou olhando pra mim e disse assim... E depois um dia eu fui ler e me decepcionei. Aí ele falou assim "Mas por quê?", porque você reduz a necessidade de etnografar o etnógrafo e reduz isso a um problema de introspecção psicológica, de onde o etnógrafo está falando. Você esqueceu que você está falando de um papel, que o etnógrafo é um papel que um antropólogo em algum momento da sua vida desempenhou. Pra você etnografar o etnógrafo você devia etnografar o etnógrafo que você foi no campo, mas você está fazendo isso no gabinete. Então começamos a discutir essa história, que é um artifício. É um artifício literário como qualquer outra coisa na escrita, não é? A não ser que seja uma lista de compra. E ficamos discutindo sobre esse problema da etnografia e da relação com as pessoas com as quais a gente convive, os conflitos que a gente tem no campo. Porque essas relações não são relações assim, "Ah, você acha?", o etnógrafo diz, aí você escreve. O etnógrafo não diz "Ah, eu não acho, eu não concordo com você". Nunca diz. Então não pode fazer um argumento contrafactual, que o Reo Fortune fez lá com os dobuenses. $\mathrm{O}$ cara dizendo pra ele que os inhames tinham alma e saíam à noite. Aí ele foi lá, foi ver como é que era. O inhame não saía nada. Ele virou pro cara e disse "Olha, o negócio é o seguinte: o cara lá da outra ladeia disse que os inhames não têm alma nenhuma, que não saem coisa nenhuma, não tem não". Aí o cara disse "Não, não é essa parte aqui de cima deles que sai, é o que tá lá embaixo. E fala baixo que eles estão ouvindo o que nós estamos falando", ele falou "Como assim?", "Peraí, fala baixo, os inhames estão ouvindo", “Estão ouvindo como?”. Aí começou a explicar, descrever o inhame, a orelha do inhame, como é que ele ouvia. Então ele foi evidenciando no argumento contra factual, tornando explícitas aquelas coisas que faziam parte dos implícitos daquela sociedade. Esse é um problema sério pra etnografia também, porque você tende a banalizar. Eu, por exemplo, com o Arno, nós dizemos isso em Quando a rua vira casa, que a etnografia urbana, casa e rua, parece que você está querendo enrolar os trouxas. Todo mundo sabe o que é. Todo mundo sabe o que é calçada, todo mundo sabe o que é rua, janela, porta, esquina. Então você descrever, fazer etnografia... Botequim, todo mundo sabe o que é. Então parece que você tá enrolando os trouxas, tá fazendo um negócio que não sei o quê, e não é bem assim. Eu, por exemplo, no Alto 
Xingu, perguntei pra um índio como é que fazia neném. Eu já tinha dois filhos. Ele disse "você sabe", e eu "eu não sei". Ele foi me explicar como é que fazia filho, e é uma ideologia da concepção completamente diferente. Não é a mesma ideologia da concepção. Todo mundo que estuda sociedades indígenas sabe disso, eu não sabia. Eu banalizava que as crianças nossas quando nascem, você levanta pelo pé assim e espera ela chorar bate até na bundinha. Quando eu fui contar isso pros índios... Eu fui assistir um parto, e eles repararam que eu estava estranhando o modo como eles faziam o parto. A criança caía com a placenta e tudo, ficava ali no chão, em cima da rede, ensanguentada. A mãe fazia um buraco do lado, um buraco, e botando as coisas pra dentro do buraco, e pegava uma coisa assim da casa, um sapê e ficava fazendo assim com a criança. A criança caída no chão lá, até que a criança chorasse. Aí alguém, se alguém pegasse e levantasse ela do chão, está tudo bem, senão, enterrava ela pra lá, morria, não nasceu né. $\mathrm{O}$ verbo alemão para nativo é o que nasce pra dentro. Pra nós nascer é sair, está associado a sair, mas em alemão é nascer pra dentro, para dentro de algum grupo, os "amigos formais", aquelas coisas todas que Matta e Melatti analisam, que você levanta a criança do chão, e aí tem a... Então às vezes essa banalização da nossa experiência nos surpreende. Eu, por exemplo, não entendia porque os índios não faziam um poço artesiano. [risos] Você é invadido por essas coisas, e aí você se dá conta que essa sua visão das coisas aparece o tempo todo em você. O etnocentrismo não é uma doença de pele que você toma um banho de Antropologia e fica bom. Toda hora ele aparece. Você tem que controlar, você tem que ter consciência disso. Então eu não sei se... para o jovem que está fazendo trabalho de campo o que eu sempre faço, primeiro eu estabeleço pra ele um lugar físico, não é um objeto teórico. Então você vai estudar isso onde? Para dar um exemplo: eu estava numa banca de mestrado, antes de viajar pra França e Soraia se inscreveu pra fazer a prova. Ela entrou muito viva como ela era, mais novinha, tem muitos anos isso, tem 15 anos, 16 anos. Entrou, ela começou a falar e começou a falar de prostitutas. Ela tinha feito umas fotografias de umas prostituas sei lá onde. Aí eu fui "Mas você quer estudar isso onde?”, "Não, quero estudar em algum lugar". Eu tinha ido ao centro administrativo e vi o desmonte da tal Vila Mimosa antiga. Eu achava que tinha que ser estudado aquilo em algum lugar. A minha preocupação não era prostituição. A minha preocupação era a reforma urbana, a revitalização urbana, esses processos. E aí eu sugeri que ela estudasse a Vila Mimosa e ela foi estudar a Vila Mimosa. Na Vila Mimosa então nós fomos discutindo, e eu sugeri 
então que ela tratasse a Vila Mimosa... Depois de ela estar fazendo a pesquisa de campo, fazendo a etnografia, que ela tratasse a Vila Mimosa como uma cidade cenográfica da prostituição carioca, e pra isso ela devia ler sobre cenografia. Ler direito para tirar as implicações da metáfora, porque cenografia tem uma porção de coisas. Eu trabalhei em cenografia com Nelson Pereira dos Santos. Tem várias coisas, tem maquiador, tem iluminador, tem cabeleireiro, tem o cara que cuida da roupa, tem o backstage, tem tudo isso que se passa nas... Como é que é?

\section{Felipe Veiga - Coxia.}

Marco Antonio - Nas coxias, né! Tem a iluminação, tem a marcação de palco, tem os desempenhos paradigmáticos, enfim... tem uma porção de coisas...

\section{Felipe Veiga - O contrarregra}

Marco Antonio - O quê? Tem os contrarregras, tem quem entra e quem não entra, como vai funcionar. Ela acabou juntando duas coisas: as preocupações dela que hoje inclusive ela desenvolve mais explicitamente em relação a uma concepção política sobre o problema do direito e as lutas, e uma dimensão propriamente etnográfica de fazer planta, de desenhar... porque eu não admitia que nenhum estudante pudesse virar antropólogo, ter o mesmo título que eu tenho sem fazer essas coisas. É quase que ritualmente. Pra você saber quando você for ler um livro de Antropologia o quanto custa fazer isso, e porque em algum momento foi importante alguém ter feito isso. Uma genealogia, uma planta, uma planta baixa, um croqui. Porque não adianta dizer que moram vinte pessoas num apartamento da Cruzada. Qual é o tamanho do apartamento? Você sabe disso, inclusive na posição que você tem no ISER, por exemplo, que os nossos alunos de Ciências Sociais não sabem a população do Rio de Janeiro, não sabem a população da cidade do Rio de Janeiro, não sabe a população da favela. Não sabe nada! E você é confrontado com isso quando você vai para fora do Brasil e o cara pergunta pra você, porque eles sabem! Um francês, um parisiense sabe exatamente tudo isso, nome, quantidade, uma pessoa minimamente ilustrada. O ilustrado aqui não sabe. Eu já ouvi gente que é formador de opinião dizer que tem sessenta mil pessoas no morro Santa Marta. Eu ouvi em Paris dizer que tinha um milhão de habitantes na Rocinha. 
Então isso é uma coisa impressionante. A escala cria, dá uma visão completamente equivocada. Quando Ciudad Bolívar em Bogotá, tem um milhão e quatrocentos mil habitantes. Isso é maior, é quase maior, pouquinho menor do que toda a população de favelados no Rio de Janeiro inteiro. Então como é que pode? Você está justificando? Não, eu estou dizendo que é equacionável, um lugar que tenha mil e quinhentas pessoas pô não é um lugar que tem um milhão. É diferente... que tem quinhentos mil! Quinhentos mil é Niterói inteira, região oceânica, tudo, quinhentos mil, um monte de edifício, um monte de gente.

Felipe Veiga - Brasília são trezentos e cinquenta mil.

Marco Antonio - Pois é!

Felipe Veiga -... a cidade. Distrito Federal são dois milhões, Brasília são trezentos e cinquenta mil.

Marco Antonio - Entendeu? Então eu acho que as escalas também são importantes, então acho difícil. Agora uma coisa também é o cuidado com a escrita. O não comprometimento com o vocabulário muito pseudo técnico. Ele tem que pensar num leitor seu que não é um imbecil, uma pessoa que está gostando de ler você. Mas você tem que fazer com que ele goste de ler você, porque tem textos que a pessoa não consegue passar da segunda página, porque faz mal ao espírito. Eu digo: eu não leio. Não adianta escrever. Isso vai me fazer mal, eu vou ficar revoltado e não vou conseguir ler mais. É uma reação! Não é uma relação de frescura não, é uma reação mesmo. Então eu acho uma falta de respeito. É uma coisa que Howard Becker custou a entender em relação ao Everett C. Hughes. Ele dizia que ele depois passou a ensinar aos alunos e teve dificuldade de fazer os alunos compreenderem o que era reescrever, reler, reescrever. Não era simplesmente entregar pra uma pessoa fazer um copy-desk, não era isso. Era clarificar cada vez mais suas questões num texto cada vez mais preciso. O Oracy Nogueira era um exemplo pra mim de beleza de texto etnográfico.

Hélio Silva - Aliás, entre os escritores de literatura é um truísmo. Escrever é reescrever. 
Marco Antonio - Meu avô dizia que escrever era cortar palavra. Graciliano tinha horror de "quê". As pessoas que trabalhavam com ele no jornal diziam que ele gritava "quê, quê é o caralho". Ele ficava puto de botarem quê, quê, quê em tudo.

Hélio Silva - Aqueles poeminhas deste tamanhozinho de João Cabral de Mello Neto ele ficava escrevendo quatro, cinco, seis meses.

Marco Antonio - É claro, porra, é lógico. Agora você imagina esse trabalho do cuidado, isso não é.. As pessoas às vezes confundem. Quem me conhece acha que eu sou uma pessoa que trava os estudantes, porque eu sou perfeccionista. "Ah, o Mello é perfeccionista, o cara não vai defender tese nunca". Isso não é verdade. Todos os meus estudantes defenderam os seus trabalhos todos dentro do prazo. Os que não foram à luta pra publicizar, não foram porque não quiseram. E todos os trabalhos são desiguais. Evidentemente são pessoas diferentes, são assuntos diferentes, são dedicações diferentes, são empenhos diferentes. Você também tem que ter maturidade como orientador pra conviver com isso. Tem estudantes que fizeram mestrado comigo, e que depois pensaram em fazer o doutorado e eu dizia "Comigo não, de jeito nenhum. Não pense nisso, nessa maldade comigo, que eu não suportarei você mais uma vez na minha vida. Não adianta, porque eu fui até onde eu podia ir com você, o máximo que eu pude. Já prestei um grande favor à humanidade. Daqui pra frente você resolve o que você quiser". Uma outra dificuldade que você tem com o estudante frequentemente é dizer para o estudante que etnografia não é furo de reportagem. Essa síndrome existe pra toda parte. Que você tem que encontrar um assunto, um objeto que nunca ninguém estudou, que nunca ninguém fez. Zacarias tem dezessete teses antes de Gente das Areias, dezessete. José Flávio ficava preocupado, "pode escrever quem quiser. Pode botar duzentas, não tem problema nenhum. O meu futebol é o meu futebol." O Arno dizia assim: "Olha, passou um filme lá no Centro Cultural do Banco do Brasil. Não falaram de você, mas o título é esse 'A lagoa é a lavoura do pescador'." Eu digo "Pode botar, mas não entendeu nada. Isso aí pegou carona", meus ex-alunos, por bobagem, exmulher por ressentimento, bobagem, por besteira. Pode fazer o quiser, quanto mais gente escrever melhor. Eu aproveitei todos que estudaram, tudo aquilo que eu podia de tirar de melhor. Você sabe quem é que num trabalho absolutamente despretensioso foi a pessoa mais sensível para estudar a pesca em Zacarias, a pesca em Maricá? Foi Stella 
Amorim. Stella Amorim foi trabalhar naquele projeto que o IBGE financiou sobre hábitos alimentares, lembra?

Hélio Silva - Me lembro.

Marco Antonio -... que o Otávio coordenou[o projeto] e o outro coordenou lá, o Wortmann, coordenou lá em Brasília, juntou todo mundo.

Hélio Silva - Censo alimentar.

Mas então, mostrar pro estudante que etnografia não é furo de reportagem é uma coisa dificílima às vezes. E difícil fazer com que o estudante use o que foi escrito antes dele sobre o assunto dele de uma maneira produtiva e generosa. É dificílimo. Às vezes tem um livro escrito sobre o mesmo assunto que você está escrevendo, e a pessoa "Não, não, mas ele escreveu outra coisa". Não é outra coisa não. Você tem que mostrar tudo aquilo que ajude. "Isso é outra coisa, não interessa". Claro que é outra coisa, está entendendo? É muito difícil. A outra coisa é lutar no grupo de pesquisa que você reúne com os seus estudantes, coisa também que não é comum, que não existe assim pelo Brasil afora, nem fora do Brasil não é comum, que é lutar contra o que eu chamo de síndrome de Charles Chan, que é aquela "apaga a luz que eu quero acender a minha lanterna". Lembra do Charles Chan?

Hélio Silva - [risos]. Lembro, mas ele nunca disse isso pra mim.

Marco Antonio - Eu que inventei! No "Balança mas não cai”, o filho do Charles Chan, toda vez que ele aparecia, a primeira coisa que ele dizia "apaga a luz que eu quero acender a minha lanterna", porque o detetive tem que ter a lanterna pra procurar as coisas. Síndrome de Charles Chan não é mole não, porque você quer apagar todo mundo pra você brilhar. Isso significa que se você não superar isso, você não compartilha a sua etnografia com ninguém pra discutir, reconhecendo como interlocutor competente que vai ajudar você, que não vai roubar suas ideias. E existe isso, existe. Existem pessoas que são caras de pau, gravam tudo que você falou e vão lá e escreve um artigo. Eu já vi isso acontecer. Mas pra mim não é uma regra. Eu nunca tive essa experiência. A primeira vez que eu tive essa experiência eu saí atrás da pessoa com uma foice de verdade na rua. Alex Varela dizendo "Que isso, cara. Pelo amor de Deus", os operários todos gritando. Eu encostei o cara no muro com uma foice... 
Hélio Silva - Você tem uma foice em seu apartamento?

Marco Antonio - Tinha, atualmente não tenho não, se você puder...

[Risos]

Porque ele disse que tinha tido umas ideias e as ideias eram exatamente as minhas ideias do meu trabalho. Tem gente que é assim. Você fala pro cara uma coisa, e daqui a cinco minutos o cara repete tudo pra você como se fosse dele. Aí você "Não, não! Isso eu acabei de dizer pra você!” Não tem? Você não conhece ninguém assim não?

Hélio Silva - Conheço, conheço.

Marco Antonio - Eu tive uma secretária de departamento que era assim. Eu dizia para ela uma coisa pra ela fazer. Ela daqui a pouco dizia "ô, Mello, você tem que fazer isso", "Mas eu acabei de dizer que você tem que fazer isso". [risos] Então sobre o negócio da orientação, quer dizer, também tem um outro problema. No campo das ciências naturais o orientando não tem projeto nenhum, quem tem projeto é o professor. No meu caso específico acontece a mesma coisa. Isso quem me chamou a atenção foram os meus colegas de Física e de Biologia Marinha. Quando eu estava fazendo um seminário, discutindo, eles "mas você fazem igual a gente". E eles me disseram "Engraçado, na área de vocês é como se vocês não tivessem nada com o trabalho do orientando, porque na banca, na nossa área, a porrada é em cima do orientador." Porque o projeto do orientador, as ideias que o orientador tinha para serem desenvolvidas é que são uma merda, e às vezes é difícil quando o orientando consegue dar uma volta por cima do falso problema, da coisa, que não quer jogar o futebol pra frente. Ele quer insistir num troço que tá lá atrás. No meu caso não, no meu caso estou identificado com as questões que foram colocadas a partir de um problema empírico. Claro que a tese de Felipe é Felipe. A tese de Soraya é a tese de Soraya. A tese de Leticia é a tese de Leticia. Mas em todas elas tem a constituição de um campo empírico comum, um interesse do orientador, problemas que de algum modo o orientador acha que serão relevantes de serem tratados, mas ele não tratou e nem vai tratar, a não ser se você aceitar o convite e generosamente me ajudar a matar essa curiosidade toda. Eu não vou escrever sobre esse assunto. Felipe, por exemplo, quando veio de Brasília, ele já vinha com mais ou menos com tudo arrumado na cabeça dele sobre como é que ele ia fazer a dissertação dele. Tinha muitas informações, tinha trabalho de campo, tinha um material iconográfico, 
tinha tudo. Só que ele não sabia uma coisa: como é que se estruturava aquilo tudo, porque ele estava orientado por uma outra concepção sobre a análise de uma manifestação da envergadura da festa do divino no Espírito Santo em Pirenópolis.

Felipe Veiga - Eu estava orientado por outra disciplina! Eu vinha de outra área. Isso era complicado. Eu tinha outra formação.

Marco Antonio - Era mais complicado ele saber que eu não ia a Pirenópolis, não queria ir a Pirenópolis, não queria ver nada de cavalhada em Pirenópolis. Eu tinha estudado a festa do divino no Catumbi, também não tinha escrito sobre ela, tinha orientado. Mas ele tinha certeza que aquele troço todo não ia por um caminho que realmente ele saísse dali dizendo "eu aprendi alguma coisa nova pra mim mesmo e li coisas que me ajudaram a compreender melhor aquilo que eu trazia comigo também”. Ninguém pode vir como diz o Carneiro Leão, naquele Aprendendo a ensinar, ninguém pode vir de mão vazias pra um encontro. Você tem sempre que trazer alguma coisa, mas também tem que estar aberto pra que isso possa se desenvolver em outras direções.

Felipe Veiga - Também não pode vir de mão cheia, né? Saber tudo!

Marco Antonio - Também não pode vir de mão cheia completamente, "sabe tudo". O que é difícil às vezes porque aí vai ser o que o Marcos Almir Madeira me dizia "Eu prefiro os antropólogos que os sociólogos" e ele era sociólogo. E eu dizia "Por quê?",

Hélio Silva - Foi meu professor.

Marco Antonio - Porque os sociólogos, ele usava a expressão em francês, eles são "Stock de reponsé". Ele falava tão empolado que a mãe dos meus filhos achava que era um estrangeiro que estava no telefone.

Hélio Silva - Ele era do Pen Clube.

Marco Antonio - Isso! Ele era do Pen Clube. Então... esse estoque de respostas é um problema, porque o problema não são as respostas, são as perguntas que você faz, as perguntas que surgem no campo. Eu não sabia de galinha d'Angola, nada disso. Eu não sabia negócio da lagoa, pescador. Eu não podia saber nada disso antes. Agora é possível reconhecer em todos esses trabalhos alguma coisa em comum? É, são trabalhos de antropólogos. Antropólogos que se identificaram de vários modos em diferentes 
momentos. Eu e Kant num primeiro momento, depois nós nos afastamos, porque temos estilos diferentes. Temos maneiras de nos colocar diferentes no campo acadêmico e maneiras de responder às inquietações diferentes. O Kant é um pouco mais pragmático, digamos assim. Flavio também era, o que gerava muitas discussões. Mas Flavio era mais dócil, mais educado, digamos assim, do que muitos colegas que às vezes são indóceis e não querem saber daquilo. Graças a essas dificuldades nascem questões importantes. Outro ponto importante que eu considero uma importante contribuição nossa, minha, de Arno e de Flavio para a etnografia dos cultos afro-brasileiros é por que o Iaô vai à missa, porque nenhum antropólogo me respondeu satisfatoriamente a isso. As respostas foram sempre de uma pobreza sociológica incrível. Todos os filósofos, nossos colegas filósofos da época, todos passam longe disso. Continuam com aquela coisa de ressuscitar uma África mítica e de não compreender certas partes do mundo dos ritos, inclusive, restituindo a força política deles. Esse último capítulo de Gente das Areias surgiu exatamente por causa dessa briga minha com o Flavio. Arno ficou apavorado porque eu podia jogar o livro por água abaixo, porque Flavio disse que eu estava botando grego demais na nossa conversa, não no texto. Porque eu lendo as cosmologias africanas parecia muito com aquele negócio do mundo das ideias, o mundo platônico, daí o Borí - a divina proporção, que foi o título do capítulo, que só foi possível por causa da etnobotânica, o princípio do gún e do èrò, que está lá na classificação botânica, na classificação dos seres da natureza que o Flavio tinha trazido. Matou a charada do Borí pra mim. Então eu falei "Então porque que Iaô vai à missa?", "Vai por uma concessão à igreja católica da classe dominante". Eu falei "Isso é de uma pobreza sociológica monumental. Vai ensinar o padre a rezar missa? Eu sou antropólogo igual a você. Aí ele saiu chateado pela porta afora, saiu chateado, ficou ofendido porque eu dei uma porrada nele assim. Aí "Pô, você vai brigar com o Flavio agora?'Umas duas semanas depois o Flavio voltou cheio de anotação, fumando muito. Ele foi a missa de Iaô e ficou impressionado. Falou "Pô, como é que pode?", eu falei “pois é, como é que pode ter tirado isso da etnografia?". Nego maquiou a etnografia propositadamente. Roger Bastide, Edson maquiaram! Porque eles falam "no domingo subsequente às cerimônias do panán vão incorporadas acompanhadas de um mais velho à missa" ponto, estão feitas e mudou o assunto! Roger Bastide diz no meio de um parágrafo: "andam de braço com o marido, ouvem rádio, vão à missa, mexem em dinheiro". Que é isso? 
Felipe Veiga - Tá de sacanagem!

Marco Antonio - Tá de sacanagem? É só pegar o livro lá. Demorou pô! Porque não é possível. Agora isso não acontece assim por um desejo de colocar... não, eles são maravilhosos. Eles são etnógrafos esplendorosos, brilhantes!

Marco Antonio - Então é isso, quer dizer, eu acho que tem essas coisas todas. É difícil uma forme, como dizem os franceses, pra resolver isso. Agora...

Hélio Silva - Se não fosse difícil, Mello, eu não teria lhe convidado.

Recebido em: 18/03/2015

Aprovado em: 10/06/2015 